\title{
Effect of shrimp farm effluent on water and sediment quality parameters off the coast of Sonora, Mexico
}

\section{Efecto de efluentes de granjas camaronícolas sobre parámetros de la calidad del agua y del sedimento frente a la costa de Sonora, México}

\author{
Ramón Héctor Barraza-Guardado ${ }^{1}$, Luis Rafael Martínez-Córdova ${ }^{1 *}$, Luis Fernando Enríquez-Ocaña ${ }^{1}$, \\ Marcel Martínez-Porchas², Anselmo Miranda-Baeza³, Marco Antonio Porchas-Cornejo ${ }^{4}$ \\ ${ }^{1}$ Departamento de Investigaciones Científicas y Tecnológicas de la Universidad de Sonora, Blvd Luis D. \\ Colosio s/n entre Reforma y Sahuaripa, Edificio 7G, Hermosillo, Sonora, México. \\ ${ }^{2}$ Centro de Investigación en Alimentación y Desarrollo, Km 0.6 Carr. La Victoria, Hermosillo, Sonora, \\ México. \\ ${ }^{3}$ Universidad Estatal de Sonora, Carretera a Huatabampo y Periférico, Navojoa, Sonora, México. \\ ${ }^{4}$ Centro de Investigaciones Biológicas del Noroeste, Unidad Guaymas, Guaymas, Sonora, México. \\ * Corresponding author. E-mail: lmtz@guaymas.uson.mx
}

\begin{abstract}
The effect of shrimp aquaculture effluents on some environmental parameters of the receiving coastal waters was assessed. Water and sediment samples were taken at different distances from the discharge point $(50,150$, and $300 \mathrm{~m})$ when shrimp farms had ceased operations (survey 1), had initiated operations (survey 2), and during the early harvest (survey 3). Water and sediment samples were likewise taken at the same distances from the shore in a non-impacted area. During surveys 1 and 2, the effluents had a negative effect at all three distances (50, 150 , and $300 \mathrm{~m}$ ) on the water quality variables (transparency, seston [total suspended solids, total inorganic solids, particulate organic matter], chlorophyll $a, \mathrm{~N}_{-} \mathrm{NO}_{2}{ }^{-}, \mathrm{N}_{-} \mathrm{NO}_{3}{ }^{-}, \mathrm{N}_{-} \mathrm{NH}_{4}{ }^{+}$), on the sediment quality parameters (organic nitrogen), and on the TRIX index. Contrarily, no differences were observed when the impacted and non-impacted areas were compared during survey 3 , probably because the effluents had diminished due to the premature harvesting. The results suggest that at the end of the farming period, the nutrient and organic matter load exceeded the assimilation capacity of the ecosystem, whereas during the recess period, the environment was capable of assimilating the excess organic matter accumulated. The levels reached by the monitored parameters did not exceed the limits established and the impact on the ecosystem is not severe, but they could represent a risk factor in the long term. Additionally, there is evidence that the temporary suspension of shrimp farming operations is beneficial for the environment.
\end{abstract}

Key words: aquaculture, effluents, shrimp farms, environmental impact, ecological impact.

RESUMEN. Se evaluó el efecto de las descargas de un parque acuícola sobre los parámetros ambientales de las aguas costeras receptoras. Se tomaron muestras de agua y sedimento del medio a diferentes distancias del punto de descarga (50, 150 y $300 \mathrm{~m})$ cuando las granjas se encontraban al final del ciclo de cultivo (muestreo 1), durante la etapa de operación (muestreo 2) y durante la cosecha prematura de las granjas (muestreo 3). También se recolectaron muestras de agua y sedimento a las mismas distancias de la costa en una zona no impactada. Se observó que durante los muestreos 1 y 2, las descargas tenían un impacto negativo a todas las distancias (50, 150 y $300 \mathrm{~m})$ sobre los parámetros de la calidad del agua (transparencia, concentración de seston [sólidos suspendidos totales, sólidos inorgánicos totales y materia orgánica particulada], clorofila $a, \mathrm{NO}_{2}^{-}, \mathrm{NO}_{3}^{-}, \mathrm{NH}_{4}^{+}$), sobre los parámetros de la calidad del sedimento como nitrógeno total y sobre el índice TRIX. En contraste, no se observaron diferencias significativas al comparar la zona impactada con la no impactada durante el muestreo 3, quizás porque disminuyeron las descargas de aguas residuales casi en su totalidad debido al cierre prematuro de los cultivos. Los resultados sugieren que al final del ciclo de cultivo, la acumulación de nutrientes y materia orgánica rebasa la capacidad de asimilación del medio, mientras que durante el período de receso, el medio es capaz de asimilar el exceso de materia acumulada. Los niveles alcanzados por los parámetros monitoreados no exceden los límites máximos establecidos y el impacto sobre el medio no es severo, pero esto podría representar un factor de riesgo a largo plazo. Además, hay evidencia de que el receso en las operaciones de las granjas resulta benéfico para el medio.

Palabras clave: actividad acuícola, efluentes, granja acuícola, impacto ambiental, impacto ecológico.

\section{INTRODUCTION}

Coastal areas are of particular ecological and economic importance as they provide direct and indirect goods and services to society, especially those related to productive activities like fishing, tourism, aquaculture, among others. It is

\section{INTRODUCCIÓN}

La zona costera es de especial importancia ecológica y económica ya que proporciona bienes y servicios directos e indirectos a la sociedad, especialmente a través de actividades productivas tales como la pesca, el turismo, la 
therefore important to establish the ecological values of coastal ecosystems in order to maintain the desired environmental conditions (Lundin 2000, Wulff et al. 2001). The coast or littoral can be considered a marine "nursery and pantry". Shallow coastal waters can have higher bioproductivity than the most productive areas on land (Rosenberg 1985). The three functional groups of primary producers (phytoplankton, benthic algae, and macrophytes) are present in coastal areas but not necessarily in the open sea, and where there is high primary productivity, there is also high secondary productivity of zooplankton, zoobenthos, fish, and crustaceans (Hakanson and Boulion 2002).

Despite its undeniable ecological value, the coastal zone receives a variety of pollutants, including those of industrial (Dell'anno et al. 2002), agricultural (Noriega and Araujo 2009), urban (Mearns 1981), and aquacultural (Primavera 2006, Kern 2011) origin. Many coastal areas worldwide are currently experiencing eutrophication and/or hypernutrification, with negative consequences for the health of the ecosystems.

Aquaculture is an important economic activity worldwide. It generates employment, foreign currency, and food products of high nutritional value and accessible to a wide sector of the population. Nonetheless, it has been strongly criticised for the serious ecological problems it can cause, especially those related to the environmental impact of its effluents (Martínez-Córdova et al. 2009, Martínez-Porchas and Martínez-Córdova 2012). These impacts are primarily associated with the high organic load and high nutrient concentrations in the effluents, which in turn are the result of inappropriate management practices (mainly feeding and fertilization) of the culture systems. The main water components that are affected by aquaculture effluents are nitrogen and phosphorus (organic and inorganic fractions), organic matter (mainly in particulate form of diverse origin), and suspended solids (Casillas-Hernández et al. 2006, MirandaBaeza et al. 2007).

Globally, several studies have been conducted on the effect of aquaculture discharges on the receiving water bodies (Molnar et al. 2014, Nóbrega et al. 2014, Suárez-Abelenda et al. 2014). In Mexico, however, few such studies have been carried out (Páez-Osuna 2001), especially in the northwestern part of the country where most of the shrimp farms are located (Páez-Osuna et al. 2003, Montaño-Ley and PáezOsuna 2014).

In northwestern Mexico, aquaculture (mainly shrimp farming) has grown rapidly over the past two decades. Production reached 130,000 $\mathrm{t}$ in 2009, making Mexico the sixth largest producer in the world (FAO 2012). Sonora contributed $37 \%$ of this production and the state's main shrimp farming area is Kino Bay (CONAPESCA 2011). This activity has generated important economic and social benefits for the state, but it has also generated environmental effects that have not been evaluated systematically. In particular, the acuicultura, entre otras. Por ello es importante establecer el valor ecológico de los ecosistemas costeros con el fin de preservar las condiciones ambientales deseadas (Lundin 2000, Wulff et al. 2001). La costa o litoral puede considerarse como una despensa y guardería del mar. Las aguas costeras poco profundas pueden tener una bioproductividad más alta que las zonas más productivas del continente (Rosenberg 1985). Los tres grupos funcionales de productores primarios (fitoplancton, algas bénticas y macrófitas) están presentes en las áreas costeras, pero no necesariamente en el mar abierto. Es sabido que donde hay una alta productividad primaria, existe también una alta productividad secundaria de zooplancton, zoobentos, peces y crustáceos (Hakanson y Boulion 2002).

A pesar de su innegable valor ecológico, la zona costera es también receptora de muchos tipos de impactos ambientales, incluyendo aquéllos generados por contaminantes provenientes de la industria (Dell'anno et al. 2002), la agricultura (Noriega y Araujo 2009), las actividades urbanas (Mearns 1981) y la acuicultura (Primavera 2006, Kern 2011). Las aguas de muchas zonas costeras del mundo se encuentran en un proceso de eutrofización y/o hipernutrificación, el cual tiene consecuencias negativas para la salud de los ecosistemas.

La acuicultura es una actividad de gran importancia económica a nivel mundial como generadora de empleos, divisas y productos alimenticios de un alto valor nutricional y accesibles a un gran sector de la población. Sin embargo, ha sido fuertemente criticada por los grandes problemas ecológicos que puede llegar a ocasionar, especialmente aquéllos relacionados con el impacto ambiental de sus efluentes (Martínez Córdova et al. 2009, Martínez-Porchas y MartínezCórdova 2012). Estos impactos están mayormente asociados a la elevada carga orgánica y las altas concentraciones de nutrientes en las descargas acuícolas, las cuales a su vez son resultado de inadecuadas prácticas de manejo (sobre todo alimentación y fertilización) de los sistemas de cultivo. Los principales componentes en el agua que son alterados por los efluentes de granjas acuícolas son el nitrógeno y fósforo en ambas fracciones (orgánica e inorgánica), la materia orgánica (principalmente en forma particulada de diferente origen) y los sólidos suspendidos (Casillas-Hernández et al. 2006, Miranda-Baeza et al. 2007).

A nivel mundial se han realizado estudios relacionados con el efecto de descargas acuícolas sobre los cuerpos de agua receptores (Molnar et al. 2014, Nóbrega et al. 2014, Suárez-Abelenda et al. 2014). En México, sólo se han realizado algunos estudios (Páez-Osuna 2001), de los cuales los que corresponden al noroeste del país, que es donde mayormente se ha desarrollado la acuicultura, son escasos (PáezOsuna et al. 2003, Montaño-Ley y Páez-Osuna 2014).

En el noroeste de México, la actividad acuícola (principalmente el cultivo de camarón) creció en forma extraordinaria en las dos últimas décadas. La producción fue de más de 130,000 t en 2009, lo cual colocó a México como el sexto productor principal a nivel mundial (FAO 2012). El 
effect of effluent discharge on the coastal zone has not been properly studied.

Recent and rapid application tools are currently available that consider the use of water quality indicators for coastal management in relation to eutrophication processes, which express structural and functional properties of the affected ecosystems (Sánchez et al. 2007, dos Santos Simoes et al. 2008). These indicators can be used to assess the environmental status of ecosystems and include variables such as turbidity, oxygen saturation, chlorophyll $a$ concentration, phytoplankton, harmful cyanobacteria, macrophyte coverage, and coliform bacteria, as well as pesticides and heavy metals, among others. Some of these indicators, such as those related to primary productivity (chlorophyll and dissolved oxygen) and nutrimentals (dissolved inorganic nutrients), have been used to elaborate indices that determine the trophic state of an ecosystem and its environmental tendency (Vollenweider et al.1988). The trophic state index (TRIX) has been widely used to assess the environmental tendencies of the Adriatic and Tyrrhenian seas (Volleinweider et al. 1998) and other European coastal areas (Pettine et al. 2007). In Mexico, this index has been primarily used for the Sonora coastal zone and it has proven to be consistent and sensitive to changes in the trophic state (Elizalde-Servín 2009, Reynaga-Franco 2009).

The trophic state of an ecosystem can be defined as the rate of supply of organic matter to it (Nixon 1995). Four trophic state categories are commonly used: oligotrophic, mesotrophic, eutrophic, and hypertrophic (Pinckney et al. 2001). Changes in trophic state can indicate processes such as eutrophication.

Sediment quality is another important factor to consider in studies addressing the environmental impact of effluents. Sediment can be the final or temporary destination of many pollutants including organic matter, nitrogen and phosphorus metabolites, and heavy metals. Some of these components can be captured and buried, and remain in the sediment for a long time. The deterioration of sediment quality has an important effect on some biotic communities, especially on those that are directly associated with sediments, such as benthic fauna, macroalgae, and sea grasses. Some biological and biogeochemical processes allow exchanges between sediment and water-column components, which affects other biotic communities, such as phytoplankton and zooplankton (Troot and Alongi 2000). Some of the main effects of fish farms on adjacent sediments are reduced and anoxic conditions, high biochemical oxygen demand, hydrogen sulfide production, and decline or disappearance of benthic fauna (Wu and Lam 1994, Martínez-Porchas and MartínezCórdova 2012).

Based on the above, it is reasonable to assume that shrimp farm discharges into Mexican coastal waters will have a significant effect on some water and sediment quality parameters, as has been reported elsewhere. Hence, the objective of the present study was to evaluate the effect of discharges estado de Sonora contribuyó con el 37\% de esa producción, y bahía de Kino ha sido la principal zona productora de camarón del estado (CONAPESCA 2011). Este crecimiento generó beneficios económicos y sociales importantes para el estado y la región, pero también generó impactos ambientales que hasta ahora no habían sido evaluados de manera sistemática. Particularmente, el efecto de las descargas sobre la zona costera no había sido debidamente estudiado.

Existen herramientas recientes y de rápida aplicación que consideran el uso de indicadores de la calidad del agua para el manejo costero en relación con los procesos de eutrofización, los cuales expresan propiedades estructurales y funcionales de los ecosistemas afectados (Sánchez et al. 2007, dos Santos Simoes et al. 2008). Estos indicadores permiten determinar el estatus ambiental de los ecosistemas e involucran variables como turbiedad, saturación de oxígeno, concentración de clorofila $a$, fitoplancton, cianobacterias dañinas, cobertura de macrófitas y bacterias coliformes, así como pesticidas y metales pesados, entre otros. Algunos de éstos indicadores, como los relacionados con la productividad primaria (clorofila y oxígeno disuelto) y los nutrimentales (nutrientes inorgánicos disueltos), han sido considerados para elaborar índices que determinan el estado trófico de los ecosistemas y su tendencia ambiental (Vollenweider et al.1988). El índice del estado trófico (TRIX) ha sido utilizado ampliamente para evaluar la tendencia ambiental en los mares Adriático y Tirreno (Volleinweider et al. 1998), así como en otras costas europeas (Pettine et al. 2007). En México, este índice se ha utilizado principalmente en la zona costera de Sonora y ha demostrado ser consistente y sensible a los cambios del estado trófico (Elizalde-Servín 2009, Reynaga-Franco 2009).

El estado trófico de un ecosistema puede ser definido como la tasa de abastecimiento de materia orgánica al mismo (Nixon 1995). Normalmente se reconocen cuatro categorias del estado trófico: oligotrófico, mesotrófico, eutrófico e hipertrófico (Pinckney et al. 2001). Los cambios de estado trófico pueden expresar procesos del ecosistema, como la eutrofización.

La calidad del sedimento es también un asunto importante de considerar en los estudios sobre impacto ambiental de efluentes. El sedimento puede ser el destino final o temporal de muchos contaminantes como la materia orgánica, los metabolitos nitrogenados y fosforados, y los metales pesados. Algunos de estos componentes pueden ser capturados y sepultados, y permanecer en el sedimento por mucho tiempo. El deterioro de la calidad del sedimento tiene un efecto significativo sobre algunas comunidades bióticas, sobre todo aquéllas que están directamente asociadas al mismo, tales como la fauna bentónica, las macroalgas y los pastos marinos. Algunos procesos biológicos y biogeoquímicos permiten el intercambio entre componentes del sedimento y de la columna de agua, lo cual afecta a otras comunidades bióticas, tales como el fitoplancton y zooplancton (Troot y Alongi 2000). Algunos de los efectos más relevantes de 
from an aquaculture park (consisting of seven shrimp farms) on water and sediment quality in a coastal area of Sonora State.

\section{MATERIALS AND METHODS}

The study was carried out in central Sonora, in the region of Kino Bay, which extends from the mouth of Infiernillo Channel to Tastiota Estuary (fig. 1). Two areas were surveyed, one near effluent discharges and presumably impacted by shrimp aquaculture activities, and the other free of

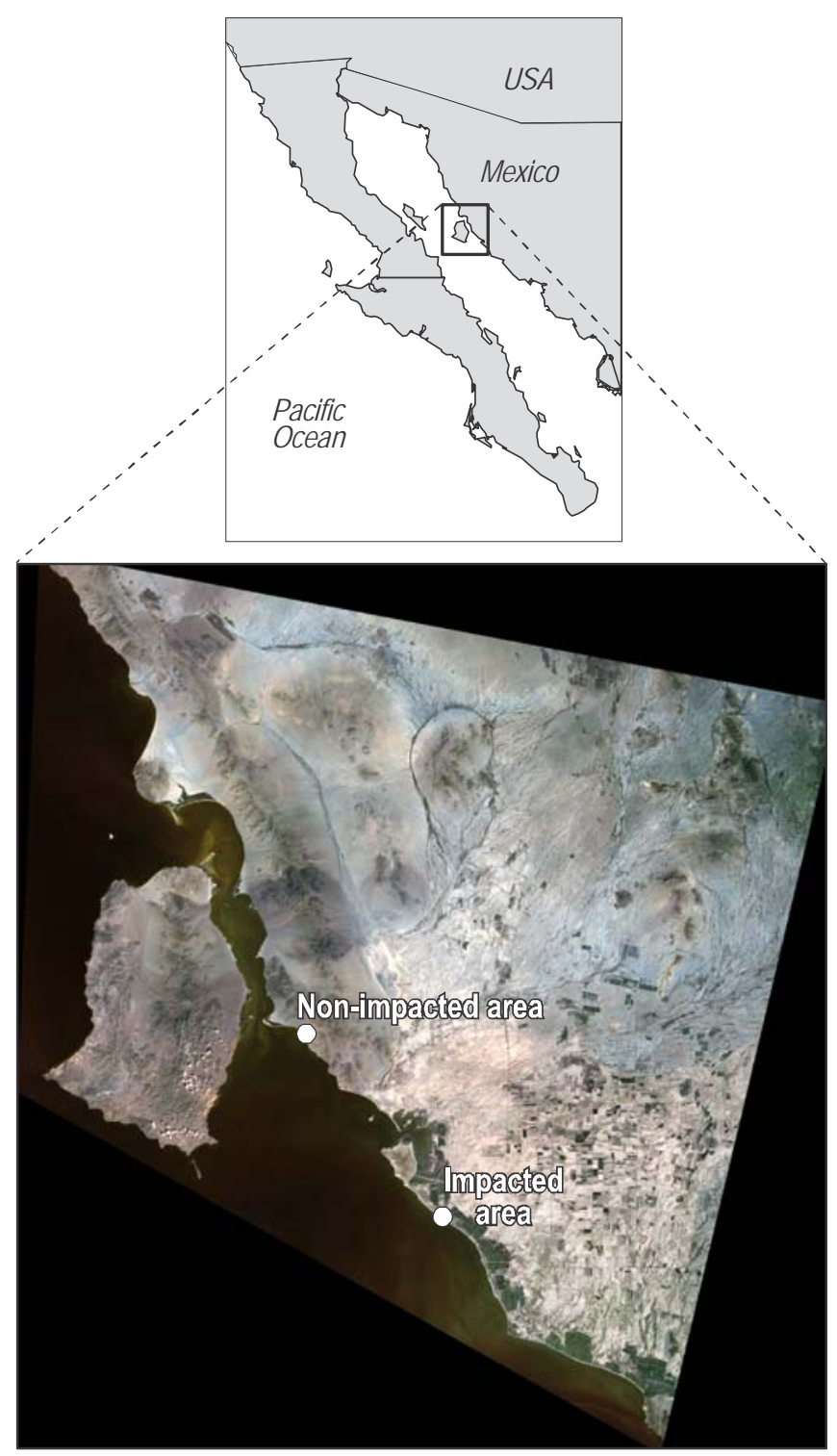

Figure 1. Location of the study area. The non-impacted area (control area) is located at a distance of around $40 \mathrm{~km}$ from the impacted area (effluent discharge area).

Figura 1. Localización del área de estudio. La zona no impactada (zona control) se encuentra a una distancia de alrededor de $40 \mathrm{~km}$ de la zona impactada (zona con descarga de efluentes). las granjas marinas de peces sobre el sedimento de áreas adyacentes son condiciones altamente reducidas y anóxicas, alta demanda bioquímica de oxígeno, producción de ácido sulfhídrico y disminución o desaparición de la fauna bentónica (Wu y Lam 1994, Martínez-Porchas y MartínezCórdova 2012).

Con base en la información mencionada, es factible suponer que las descargas de granjas camaronícolas a las aguas costeras de México tendrán un efecto significativo en algunos parámetros de la calidad del agua y del sedimento, tal como se ha registrado en otras áreas del mundo. El objetivo del presente estudio fue evaluar el efecto de las descargas de un parque acuícola (conformado por siete granjas camaronícolas) sobre la calidad del agua y del sedimento en un área costera del estado de Sonora.

\section{MATERIALES Y MÉTODOS}

El estudio se realizó en la parte central de Sonora, en la región de bahía de Kino, la cual comprende desde la boca del canal del Infiernillo hasta el estero Tastiota (fig. 1). El estudio comprendió dos zonas costeras, una ubicada justo en la descarga de efluentes de granjas camaronícolas y presumiblemente impactada por la actividad acuícola, y la otra libre de descargas y supuestamente no impactada. La zona impactada $\left(28^{\circ} 40^{\prime} 07^{\prime \prime} \mathrm{N}, 111^{\circ} 51^{\prime} 58^{\prime \prime} \mathrm{W}\right)$ recibe efluentes de un parque acuícola (aproximadamente 800 ha de cultivo), constituido por siete granjas de camarón que registran una producción anual aproximada de 2000 t. En general, las granjas manejan densidades de siembra de 15 a 25 camarones por metro cuadrado y tasas de recambio de agua variables $\left(5-30 \% \mathrm{~d}^{-1}\right)$, y practican dos ciclos de cultivo al año. Se han registrado flujos de nutrientres de $243 \mathrm{t} \mathrm{N}$ año ${ }^{-1}$ y $44 \mathrm{t} \mathrm{P}$ año ${ }^{-1}$ para un sitio contiguo $(18 \mathrm{~km})\left(28^{\circ} 46^{\prime} 19^{\prime \prime} \mathrm{N}, 111^{\circ} 51^{\prime} 58^{\prime \prime} \mathrm{W}\right)$ a nuestra zona de estudio pero con volúmenes mayores de descarga de aguas residuales (Barraza-Guardado et al. 2013). La zona no impactada $\left(28^{\circ} 56^{\prime} 12^{\prime \prime} \mathrm{N}, 112^{\circ} 05^{\prime} 40^{\prime \prime} \mathrm{W}\right)$ se ubica aproximadamente a $42 \mathrm{~km}$ al norte de la zona impactada. Ninguna de las dos áreas se encuentra cercana a los posibles aportes de nutrientes de la agricultura, por lo cual su influencia, si la hubiera, sería insignificante ya que estos aportes son actualmente muy escasos debido al represamiento de los ríos Yaqui y Mayo, y la distancia a estas zonas es de más de $100 \mathrm{~km}$. Por otro lado, el aporte de nutrientes por el efecto de las surgencias parece afectar por igual a la zona impactada por la acuicultura como a la no impactada (Santamaría-del-Angel et al. 1994, Lluch-Cota 2000).

En cada una de las zonas se llevaron a cabo tres muestreos: el primero (muestreo 1) en noviembre y diciembre de 2012, a un mes de la finalización de las operaciones de las granjas; el segundo (muestreo 2) en abril y mayo de 2013, cuando iniciaron las operaciones (30-45 días); y el tercero (muestreo 3) en agosto de 2013, cuando las granjas disminuyeron sus descargas debido al manejo de bajo recambio de agua que implementaron y debido al inicio prematuro de las 
effluents and presumably not impacted. The impacted area $\left(28^{\circ} 40^{\prime} 07^{\prime \prime} \mathrm{N}, 111^{\circ} 51^{\prime} 58^{\prime \prime} \mathrm{W}\right)$ receives the effluents of an aquaculture park (approximately $800 \mathrm{ha}$ ), consisting of seven shrimp farms that report an approximate annual production of $2000 \mathrm{t}$. The farms generally employ stocking densities of 15 to 25 shrimp per square meter and variable water-exchange rates of $5-30 \% \mathrm{~d}^{-1}$, and operate two culture cycles per year. Nutrient fluxes of $243 \mathrm{t} \mathrm{N} \mathrm{yr}^{-1}$ and $44 \mathrm{t} \mathrm{P} \mathrm{yr}^{-1}$ have been reported for an area contiguous to our study area $(18 \mathrm{~km}$; $\left.28^{\circ} 46^{\prime} 19^{\prime \prime} \mathrm{N}, 111^{\circ} 51^{\prime} 58^{\prime \prime} \mathrm{W}\right)$ but with larger volumes of sewage effluent (Barraza-Guardado et al. 2013). The nonimpacted area $\left(28^{\circ} 56^{\prime} 12^{\prime \prime} \mathrm{N}, 112^{\circ} 05^{\prime} 40^{\prime \prime} \mathrm{W}\right)$ is located approximately $42 \mathrm{~km}$ to the north of the impacted area. Neither area is located close to possible agricultural nutrient inputs, which in any case are scarce and insignificant due to the damming of the Yaqui and Mayo rivers and the distance from the agricultural lands located more than $100 \mathrm{~km}$ away. Moreover, upwelling-related nutrient inputs apparently affect the impacted and non-impacted areas in the same way (Santamaría-del-Angel et al. 1994, Lluch-Cota 2000).

Three surveys were carried out in each area: the first (survey 1) in November and December 2012, one month after the shrimp farms had ceased operations; the second (survey 2) in April and May 2013, when they had initiated operations (30-45 days); and the third (survey 3) in August 2013, when the effluent discharges declined because of the low water-exchange rates used and because farmers resorted to early harvesting in response to disease problems. In each area, three transects parallel to the coast were surveyed at distances of 50 (T1), 150 (T2), and $300 \mathrm{~m}$ (T3) from the shore. Three equidistant points were sampled along each transect. In the impacted area, T1 was located in the effluent and sea mixing zone, whereas T2 and T3 were located close to the mixing zone. The depth ranged from 1.53 to $2.17 \mathrm{~m}$ along $\mathrm{T} 1$, from 4.8 to $6.4 \mathrm{~m}$ along T2, and from 7.8 to $8.17 \mathrm{~m}$ along T3. In the non-impacted area, the depth ranged from 2.0 to $2.6 \mathrm{~m}$ along T1, from 3.8 to $4.9 \mathrm{~m}$ along $\mathrm{T} 2$, and from 5.2 to $6.3 \mathrm{~m}$ along T3. The surveys were conducted at 08:00 and 12:00 hours, without taking tide level into account, to avoid the strong winds that normally predominate in the afternoon. A boat with a 75-HP outboard motor was used for all the surveys.

Direct temperature $\left( \pm 0.1^{\circ} \mathrm{C}\right)$, dissolved oxygen (concentration $\pm 0.1 \mathrm{mg} \mathrm{L}^{-1}$ and $\%$ saturation \pm 1$)$, and salinity $( \pm 0.1)$ measurements were taken at each sampling point with a YSI 85 meter (YSI Inc., Yellow Springs, Ohio, USA). The meter was previously calibrated following the manufacturer's indications and in the case of dissolved oxygen, the measurements were compared with those obtained by the Winkler method (Strickland and Parsons 1972). In the case of salinity, a standard solution to measure conductivity was used. For the pH measurements, a Hanna potentiometer (model 220A), calibrated using buffer solutions $\mathrm{pH} 7.0$ and 10.0, was used. Water transparency and depth were measured with a Secchi disk. cosechas por problemas de enfermedades. En cada zona se muestrearon tres transectos paralelos a la costa y a distancias de 50 (T1), 150 (T2) y 300 m (T3) mar adentro. En cada transecto se ubicaron tres puntos de muestreo equidistantes entre sí. En la zona impactada, T1 quedó ubicada en la zona de mezcla del efluente con el mar, y T2 y T3 quedaron ubicados cerca de la zona de mezcla; las profundidades variaron de 1.53 a $2.17 \mathrm{~m}$ para $\mathrm{T} 1$, de 4.8 a $6.4 \mathrm{~m}$ para $\mathrm{T} 2$ y de 7.8 a $8.17 \mathrm{~m}$ para T3. En la zona no impactada, la profundidad varió de 2.0 a $2.6 \mathrm{~m}$ para T1, de 3.8 a $4.9 \mathrm{~m}$ para T2 y de 5.2 a $6.3 \mathrm{~m}$ para T3. Los muestreos se realizaron de las 08:00 a la 12:00 horas sin tomar en cuenta el nivel de la marea, esto para evitar los vientos fuertes que predominan normalmente durante la tarde. Para realizar los muestreos, se utilizó una embarcación con motor fuera de borda de 75 HP.

En cada estación se midieron directamente la temperatura $\left( \pm 0.1^{\circ} \mathrm{C}\right.$ ), el oxígeno disuelto (concentración $\pm 0.1 \mathrm{mg} \mathrm{L}^{-1} \mathrm{y}$ $\%$ de saturación \pm 1$)$ y la salinidad $( \pm 0.1)$ con un oxímetro de campo YSI 85 (YSI Inc., Yellow Springs, Ohio, USA). El oxímetro fue calibrado previamente de acuerdo con las indicaciones del manual del fabricante y para el caso del oxígeno disuelto, las mediciones fueron comparadas con las obtenidas mediante el método de Winkler (Strickland y Parsons 1972). Para el caso de la salinidad, se utilizó una solución estándar para medir la conductividad. El pH se midió con un potenciómetro Hanna (modelo 220A), el cuál fue calibrado utilizando soluciones amortiguadoras de $\mathrm{pH} 7.0$ y 10.0. La transparencia del agua y la profundidad se determinaron con un disco de Secchi.

Para la determinación de clorofila $a$, nutrientes disueltos y seston, las muestras de agua fueron recolectadas en botellas de plástico de $1 \mathrm{~L}$ y transportadas en hielo molido al laboratorio de calidad del agua, donde inmediatamente fueron filtradas y congeladas para su posterior análisis. La concentración de clorofila $a$ fue determinada usando la metodología descrita por Parsons et al. (1984). La concentración de seston (sólidos suspendidos totales, sólidos inorgánicos totales y materia orgánica particulada) fue determinada siguiendo los procedimientos descritos por Strickland y Parsons (1972) y APHA (1992).

Se emplearon técnicas estandarizadas para la determinación de los nutrientes (APHA 1998). Se utilizó el método de reducción de cadmio (intervalo de 0.01 a $0.5 \mathrm{mg} \mathrm{L}^{-1} \mathrm{~N}-\mathrm{NO}_{3}^{-}$) para la cuantificación de nitratos y el método de diazotización (intervalo de 0.002 a $0.300 \mathrm{mg} \mathrm{L}^{-1} \mathrm{~N}^{-\mathrm{NO}_{2}}{ }^{-}$) para los análisis de nitritos. Para determinar el nitrógeno amoniacal, se empleó el método del salicilato (intervalo de 0 a $0.5 \mathrm{mg} \mathrm{L}^{-1} \mathrm{~N}^{-} \mathrm{NH}_{4}^{+}$). Los ortofosfatos fueron determinados por el método de ácido ascórbico (intervalo de 0.02 a $2.5 \mathrm{mg} \mathrm{L}^{-1} \mathrm{P}_{-} \mathrm{PO}_{4}^{-}$).

El nitrógeno total por Kjehldal (NTK) en agua fue determinado mediante el método de digestión con ácido sulfúrico concentrado en un digestor Digesdahl a $440{ }^{\circ} \mathrm{C}$ durante 5 min, agregando peróxido de hidrógeno al 50\% para finalizar la digestión. El sobrenadante se trató por el método 8075 
To determine chlorophyll $a$, dissolved nutrients, and seston, water samples were collected in 1-L plastic bottles and transported on ice to the water-quality laboratory, where they were immediately filtered and frozen until further analysis. Chlorophyll $a$ concentration was determined according to Parsons et al. (1984). Seston (total suspended solids, total inorganic solids, and particulate organic matter) was determined following the procedures described by Strickland and Parsons (1972) and APHA (1992).

Standardized techniques (APHA 1998) were used for the determination of nutrients. The cadmium reduction method (range: 0.01 to $0.5 \mathrm{mg} \mathrm{L}^{-1}{\mathrm{~N}-\mathrm{NO}_{3}}^{-}$) was used for the quantification of nitrate, and the diazotization method (range: 0.002 to $0.300 \mathrm{mg} \mathrm{L}^{-1}{\mathrm{~N}-\mathrm{NO}_{2}}^{-}$) was used for the analysis of nitrite. Ammoniacal nitrogen was analyzed by the salicylate method (range: 0 to $0.5 \mathrm{mg} \mathrm{L}^{-1} \mathrm{~N}^{-\mathrm{NH}_{4}}{ }^{+}$). For the determination of orthophosphates, the ascorbic acid method (range: 0.02 to $\left.2.5 \mathrm{mg} \mathrm{L}^{-1} \mathrm{P}_{-} \mathrm{PO}_{4}^{-}\right)$was used.

Total Kjeldahl nitrogen (TKN) in water was determined by the digestion method with concentrated sulfuric acid in a Digesdahl digester at $440{ }^{\circ} \mathrm{C}$ for $5 \mathrm{~min}$, adding $50 \%$ hydrogen peroxide to finalize the digestion. The supernatant was treated by $\mathrm{HACH}$ method 8075 , and $1 \mathrm{~mL}$ of Nessler reagent was added as the final step. Absorbance was measured by a HACH DR 2800 spectrophotometer.

For the determination of TKN in sediments, $10 \mathrm{~g}$ of sample was dried for $48 \mathrm{~h}$ in an oven at $60^{\circ} \mathrm{C}$ until constant weight was reached. The sample was placed in a $100-\mathrm{mL}$ volumetric flask with $4 \mathrm{~mL}$ of concentrated sulfuric acid, and the same procedure used for the water samples was then followed.

To establish the trophic state of both study areas, the TRIX index was applied to determine the environmental condition, the organic and nutrient load, and the possible trend towards eutrophication. This multivariate index, proposed by Vollenweider et al. (1988), is expressed as follows:

$$
\mathrm{TRIX}=\left(\left[\log _{10}((\mathrm{Chl} a) \times|\% \mathrm{DOd}| \times \mathrm{DIN} \times \mathrm{SRP})+K\right]\right) / m
$$

where Chl $a$ is the concentration of chlorophyll $a\left(\mu \mathrm{g} \mathrm{L}^{-1}\right)$; $|\% \mathrm{DOd}|$ is the absolute deviation from the dissolved oxygen percent saturation (i.e., [100-\%DO]); DIN is dissolved inorganic nitrogen, $\mathrm{N}$ as $\left[\mathrm{N}_{-} \mathrm{NO}_{3}^{-}+\mathrm{N}^{-} \mathrm{NO}_{2}^{-}+\mathrm{N}^{-} \mathrm{NH}_{4}^{+}\right]$ $\left(\mu \mathrm{g} \mathrm{N} \mathrm{L}^{-1}\right)$; and SRP is soluble reactive phosphorus ( $\mu \mathrm{g} \mathrm{P} \mathrm{L}^{-1}$ ). The constants $K=1.5$ and $m=12 / 10=1.2$ are scale coefficients introduced to fix the lowest index value and define the extension of the related trophic scale, from 0 to 10 TRIX units.

The TRIX index covers the four trophic states (ElizaldeServín 2009) and a range of four water quality conditions: high, good, poor, and bad (Penna et al. 2004, Salas et al. 2008) (table 1).
$(\mathrm{HACH})$, que incluyó como pasó final agregar $1 \mathrm{~mL}$ de reactivo de Nessler. La absorbancia fue medida en un espectrofotómetro HACH DR 2800.

Para la determinación de NTK en el sedimento, se tomaron $10 \mathrm{~g}$ de muestra y se secaron durante $48 \mathrm{~h}$ en una estufa a $60{ }^{\circ} \mathrm{C}$ hasta alcanzar un peso constante. Se colocó la muestra en matraces aforados de $100 \mathrm{~mL}$, se agregaron $4 \mathrm{~mL}$ de ácido sulfúrico concentrado y se procedió de la misma forma que con las muestras de agua.

Para establecer el estado trófico de ambas zonas estudiadas, se aplicó el índice TRIX con la finalidad de determinar la condición ambiental, la carga orgánica, la carga de nutrientes y la posible tendencia hacia la eutrofización. Este índice multivariado, propuesto por Vollenweider et al. (1988), se expresa mediante la siguiente fórmula:

$$
\text { TRIX }=([\log 10((\mathrm{Cl} a) \times|\% \mathrm{ODd}| \times \mathrm{NID} \times \mathrm{PRS})+K]) / m
$$

dónde $\mathrm{Cl} a$ es la concentración de clorofila $a\left(\mu \mathrm{g} \mathrm{L} \mathrm{L}^{-1}\right)$; $|\% \mathrm{ODd}|$ es el valor absoluto de la desviación del porcentaje de saturación de oxígeno disuelto (i.e., [100 - \%OD]); NID es el nitrógeno inorgánico disuelto, $\mathrm{N}$ como $\left[\mathrm{N}^{-\mathrm{NO}_{3}}{ }^{-}+\mathrm{N}-\right.$ $\left.\mathrm{NO}_{2}^{-}+{\mathrm{N}-\mathrm{NH}_{4}+}^{+}\right]\left(\mu \mathrm{g} \mathrm{N} \mathrm{L}^{-1}\right)$; y PRS es el fósforo reactivo soluble $\left(\mu \mathrm{g} \mathrm{P} \mathrm{L}^{-1}\right)$. Las constantes $K=1.5$ y $m=12 / 10=1.2$ son valores de escala introducidos para ajustar el valor del límite más bajo del índice y la extensión de la escala trófica relacionada, de 0 a 10 unidades TRIX.

El índice TRIX cubre los cuatro estados tróficos (Elizalde-Servín 2009) y un intervalo de cuatro estados de la calidad del agua: alta, buena, pobre y mala (Penna et al. 2004, Salas et al. 2008) (tabla 1).

\section{Análisis estadísticos}

Los datos de la calidad del agua y de los sedimentos fueron sometidos a una prueba de normalidad y homogeneidad de varianza (Conover 1980). Derivado de ello se realizaron pruebas paramétricas de análisis multivariados (MANOVA, por sus siglas en inglés), considerando un nivel de significancia de $P<0.05$ para todos los casos.

\section{RESUltados}

La temperatura, la salinidad, el oxígeno disuelto y la saturación de oxígeno disuelto variaron con respecto a la fecha de muestreo, pero no con respecto a la zona (impactada y no impactada). Sin embargo, los parámetros sólidos suspendidos totales (SST), sólidos inorgánicos totales (SIT), Clorofila $a$, $\mathrm{N}-\mathrm{NO}_{2}{ }^{-}, \mathrm{N}-\mathrm{NO}_{3}{ }^{-}, \mathrm{N}-\mathrm{NH}_{4}{ }^{+}, \mathrm{NTK}, \mathrm{P}^{-} \mathrm{PO}_{4}^{-}$, fósforo total e índice TRIX variaron con respecto a la fecha y la zona de muestro. Se registraron concentraciones significativamente mayores en la zona impactada en comparación con la zona no impactada durante los muestreos 1 y 2 , es decir, cuando las granjas terminaron e iniciaron sus operaciones. Las 
Table 1. Water quality and trophic level associated with the TRIX index.

Tabla 1. Calidad del agua y nivel trófico asociado con el índice TRIX.

\begin{tabular}{cccc}
\hline TRIX index & Water quality & Trophic level & Characteristics of the water \\
\hline $0-4$ & High & Oligotrophic & Poor productivity; low trophic level \\
$4-5$ & Good & Mesotrophic & Moderate productivity; mean trophic level \\
$5-6$ & Poor & Eutrophic & Moderate to high productivity \\
$6-8$ & Bad & Hypertrophic & High productivity; high trophic level \\
\hline
\end{tabular}

\section{Statistical analysis}

The water and sediment quality data were subjected to tests of normality and homogeneity of variance (Conover 1980). Multivariate analysis of variance (MANOVA) was then performed, considering a significance level of $P<0.05$ in all cases.

\section{RESULTS}

Temperature, salinity, dissolved oxygen, and dissolved oxygen saturation varied according to the sampling date but not according to the sampling area (impacted and nonimpacted). On the other hand, total suspended solids (TSS), total inorganic solids (TIS), chlorophyll $a, \mathrm{~N}_{-} \mathrm{NO}_{2}^{-}, \mathrm{N}_{-} \mathrm{NO}_{3}^{-}$, $\mathrm{N}-\mathrm{NH}_{4}{ }^{+}, \mathrm{TKN}, \mathrm{P}-\mathrm{PO}_{4}^{-}$, total phosphorus, and the TRIX index varied both according to sampling date and area. Significantly higher concentrations were recorded in the impacted area relative to the non-impacted area during surveys 1 and 2 (i.e., when farms ceased and initiated operations). Clorophyll $a$ and TIS were higher in the impacted area during all the surveys (table 2).

When the sampling dates were analyzed independently, in survey 1, when shrimp farming operations had ceased (table 3), the effluents were found to have a significant (negative) effect on most of the parameters considered, particularly in the first $150 \mathrm{~m}$ from the discharge point. In the impacted area there was a decline in water transparency, and TIS and TKN had significantly higher concentrations than those recorded in the non-impacted area at the distances of 50 and $150 \mathrm{~m}$. The nitrogen metabolites $\left(\mathrm{N}-\mathrm{NO}_{2}{ }^{-}, \mathrm{N}-\mathrm{NO}_{3}{ }^{-}, \mathrm{N}-\mathrm{NH}_{4}{ }^{+}\right)$, TSS, chlorophyll $a$, and TRIX index also had higher values in the impacted area relative to the non-impacted area at all three distances $(50,150$, and $300 \mathrm{~m})$.

In survey 2 , when the shrimp farms had initiated operations (table 4), the effluents continued to have a negative effect on most of the parameters. For example, in the impacted area water transparency declined in the first $150 \mathrm{~m}$ from the discharge point, and TSS, TIS, TKN, chlorophyll $a$, $\mathrm{N}-\mathrm{NO}_{3}{ }^{-}, \mathrm{N}-\mathrm{NH}_{4}{ }^{+}$, and $\mathrm{P}-\mathrm{PO}_{4}{ }^{-}$had higher values relative to the non-impacted area at all three distances $(50,150$, and $300 \mathrm{~m})$. In this case, significant changes were not recorded for the TRIX index for the non-impacted area at any of the distances. concentraciones de SIT y clorofila $a$ fueron mayores en la zona impactada durante todos los muestreos realizados (tabla 2).

Al estudiar por separado las diferentes fechas de muestreo, se detectó que cuando las granjas se encontraban hacia el final de sus operaciones (muestreo 1, tabla 3), hubo un efecto significativo (negativo) de las descargas sobre la mayor parte de los parámetros considerados, particularmente en los primeros $150 \mathrm{~m}$ a partir del punto de descarga. Se registró una disminución en la transparencia del agua en la zona impactada. Los SIT y NTK presentaron concentraciones significativamente mayores en la zona impactada que en la no impactada a 50 y $150 \mathrm{~m}$ de la costa. Los metabolitos nitrogenados $\left(\mathrm{N}-\mathrm{NO}_{2}^{-}, \quad \mathrm{N}-\mathrm{NO}_{3}^{-}, \mathrm{N}_{-} \mathrm{NH}_{4}^{+}\right)$, los SST, la clorofila $a$ y el índice TRIX también presentaron valores más altos en la zona impactada en comparación con la no impactada a las tres distancias $(50,150$ y $300 \mathrm{~m})$.

En el muestreo 2, cuando inició la operación de las granjas (tabla 4), se siguió observando el efecto negativo de las descargas sobre la mayor parte de los parámetros estudiados. Por ejemplo, hubo una disminución en la transparencia del agua en la zona impactada dentro de los primeros $150 \mathrm{~m}$ a partir del punto de descarga, y los valores de SST, SIT, NTK, clorofila $a, \mathrm{~N}_{-} \mathrm{NO}_{3}{ }^{-}, \mathrm{N}-\mathrm{NH}_{4}{ }^{+}$y $\mathrm{P}_{-} \mathrm{PO}_{4}{ }^{-}$fueron más altos en la zona impactada que en la no impactada a todas las distancias consideradas $(50,150$ y $300 \mathrm{~m})$. En este caso, no se registraron cambios significativos en el índice TRIX para la zona impactada a niguna distancia.

En el muestreo 3, cuando las granjas habían detenido sus operaciones o habían cosechado (tabla 5), se observó que la mayoría de los parámetros monitoreados fueron estadísticamente similares entre la zona impactada y la no impactada, independientemente de la distancia. Los SST fueron significativamente más altos en la zona no impactada a todas las distancias $(50,150$ y $300 \mathrm{~m})$. La materia orgánica particulada, los SIT y $\mathrm{P}_{-} \mathrm{PO}_{4}{ }^{-}$fueron más altos en la zona no impactada dentro de los primeros $150 \mathrm{~m}$ de la costa. Como efectos negativos, solamente se registró una disminución en la transparencia del agua y un aumento en la concentración de NTK del sedimento en la zona impactada dentro de los primeros $150 \mathrm{~m}$ a partir del punto de descarga.

\section{DISCUSIÓN}

Los resultados, en general, revelan un impacto negativo de los efluentes de granjas camaronícolas sobre la mayoría de 
Table 2. Water and sediment quality parameters $( \pm \mathrm{SD})$ in impacted and non-impacted areas at the end of the shrimp farming operations (1), during the farming operations (2), and during the early harvest (3).

Tabla 2. Parámetros de la calidad del agua y el sedimento $( \pm \mathrm{DE})$ en la zona impactada y la no impactada al final de las operaciones de las granjas (1), durante el inicio de las operaciónes de las granjas (2) y durante las cosechas prematuras (3).

\begin{tabular}{|c|c|c|c|c|c|}
\hline Parameter & Survey & Non-impacted area & Impacted area & $P_{\text {Area }}$ & $P_{\text {Sampling }}$ \\
\hline Temperature $\left({ }^{\circ} \mathrm{C}\right)$ & $\begin{array}{l}1 \\
2 \\
3\end{array}$ & $\begin{array}{l}19.5 \pm 0.1^{\mathrm{a}} \\
22.7 \pm 0.4^{\mathrm{a}} \\
31.6 \pm 0.2^{\mathrm{a}}\end{array}$ & $\begin{array}{l}20.6 \pm 1.3^{\mathrm{a}} \\
22.0 \pm 0.4^{\mathrm{a}} \\
31.3 \pm 0.2^{\mathrm{a}}\end{array}$ & 0.09 & 0.00 \\
\hline Salinity & $\begin{array}{l}1 \\
2 \\
3\end{array}$ & $\begin{array}{l}35.9 \pm 0.1^{\mathrm{a}} \\
34.8 \pm 0.3^{\mathrm{a}} \\
36.4 \pm 0.2^{\mathrm{a}} \\
\end{array}$ & $\begin{array}{l}36.1 \pm 0.2^{\mathrm{a}} \\
34.8 \pm 0.3^{\mathrm{a}} \\
36.1 \pm 0.4^{\mathrm{a}} \\
\end{array}$ & 0.76 & 0.00 \\
\hline Dissolved oxygen $\left(\mathrm{mg} \mathrm{L}^{-1}\right)$ & $\begin{array}{l}1 \\
2 \\
3\end{array}$ & $\begin{array}{l}6.5 \pm 0.7^{\mathrm{a}} \\
9.4 \pm 0.5^{\mathrm{a}} \\
5.6 \pm 0.2^{\mathrm{a}}\end{array}$ & $\begin{array}{l}7.2 \pm 0.7^{\mathrm{a}} \\
8.9 \pm 0.4^{\mathrm{a}} \\
5.7 \pm 0.1^{\mathrm{a}}\end{array}$ & 0.40 & 0.00 \\
\hline Dissolved oxygen saturation (\%) & $\begin{array}{l}1 \\
2 \\
3\end{array}$ & $\begin{array}{r}86.9 \pm 7.6^{\mathrm{a}} \\
109.2 \pm 5.4^{\mathrm{a}} \\
92.3 \pm 2.7^{\mathrm{a}}\end{array}$ & $\begin{array}{r}91.5 \pm 3.9^{\mathrm{a}} \\
101.6 \pm 5.9^{\mathrm{a}} \\
92.5 \pm 2.4^{\mathrm{a}}\end{array}$ & 0.57 & 0.00 \\
\hline $\mathrm{pH}$ & $\begin{array}{l}1 \\
2 \\
3\end{array}$ & $\begin{array}{l}7.9 \pm 0.0^{\mathrm{a}} \\
8.2 \pm 0.0^{\mathrm{a}} \\
8.4 \pm 0.0^{\mathrm{a}}\end{array}$ & $\begin{array}{l}7.9 \pm 0.1^{\mathrm{a}} \\
8.2 \pm 0.0^{\mathrm{a}} \\
8.4 \pm 0.0^{\mathrm{a}}\end{array}$ & 0.84 & 0.00 \\
\hline Total suspended solids $\left(\mathrm{mg} \mathrm{L}^{-1}\right)$ & $\begin{array}{l}1 \\
2 \\
3\end{array}$ & $\begin{array}{l}27.1 \pm 0.8^{\mathrm{a}} \\
22.6 \pm 2.5^{\mathrm{a}} \\
31.4 \pm 3.9^{\mathrm{a}} \\
\end{array}$ & $\begin{array}{l}29.9 \pm 1.2^{\mathrm{b}} \\
31.6 \pm 3.9^{\mathrm{b}} \\
28.5 \pm 3.7^{\mathrm{a}}\end{array}$ & 0.04 & 0.01 \\
\hline Particulate organic matter $\left(\mathrm{mg} \mathrm{L}^{-1}\right)$ & $\begin{array}{l}1 \\
2 \\
3\end{array}$ & $\begin{array}{l}4.4 \pm 0.4^{\mathrm{a}} \\
3.5 \pm 0.5^{\mathrm{a}} \\
4.9 \pm 0.5^{\mathrm{a}}\end{array}$ & $\begin{array}{l}4.7 \pm 0.4^{\mathrm{a}} \\
4.3 \pm 0.5^{\mathrm{a}} \\
3.9 \pm 0.9^{\mathrm{a}}\end{array}$ & 0.97 & 0.00 \\
\hline Total inorganic solids $\left(\mathrm{mg} \mathrm{L}^{-1}\right)$ & $\begin{array}{l}1 \\
2 \\
3\end{array}$ & $\begin{array}{l}22.6 \pm 0.7^{\mathrm{a}} \\
19.1 \pm 2.1^{\mathrm{a}} \\
25.5 \pm 4.0^{\mathrm{a}} \\
\end{array}$ & $\begin{array}{l}24.5 \pm 1.4^{\mathrm{b}} \\
27.3 \pm 3.5^{\mathrm{b}} \\
22.6 \pm 3.1^{\mathrm{a}}\end{array}$ & 0.04 & 0.02 \\
\hline Chlorophyll $a\left(\mathrm{mg} \mathrm{m}^{-3}\right)$ & $\begin{array}{l}1 \\
2 \\
3\end{array}$ & $\begin{array}{l}3.0 \pm 0.3^{\mathrm{a}} \\
1.1 \pm 0.1^{\mathrm{a}} \\
2.0 \pm 0.2^{\mathrm{a}}\end{array}$ & $\begin{array}{l}5.8 \pm 1.2^{\mathrm{b}} \\
3.1 \pm 1.5^{\mathrm{b}} \\
2.4 \pm 0.1^{\mathrm{b}}\end{array}$ & 0.00 & 0.00 \\
\hline $\mathrm{N}^{-\mathrm{NO}_{2}}{ }^{-}\left(\mathrm{mg} \mathrm{L}^{-1}\right)$ & $\begin{array}{l}1 \\
2 \\
3\end{array}$ & $\begin{array}{l}0.002 \pm 0.0004^{\mathrm{a}} \\
0.001 \pm 0.0008^{\mathrm{a}} \\
0.004 \pm 0.0005^{\mathrm{a}}\end{array}$ & $\begin{array}{l}0.005 \pm 0.0004^{b} \\
0.005 \pm 0.0004^{b} \\
0.004 \pm 0.0003^{b}\end{array}$ & 0.00 & 0.00 \\
\hline $\mathrm{N}^{-\mathrm{NO}_{3}}{ }^{-}\left(\mathrm{mg} \mathrm{L}^{-1}\right)$ & $\begin{array}{l}1 \\
2 \\
3\end{array}$ & $\begin{array}{l}0.008 \pm 0.002^{\mathrm{a}} \\
0.014 \pm 0.001^{\mathrm{a}} \\
0.006 \pm 0.004^{\mathrm{a}}\end{array}$ & $\begin{array}{l}0.011 \pm 0.001^{\mathrm{b}} \\
0.019 \pm 0.002^{\mathrm{b}} \\
0.006 \pm 0.000^{\mathrm{a}}\end{array}$ & 0.00 & 0.00 \\
\hline${\mathrm{N}-\mathrm{NH}_{4}}^{+}\left(\mathrm{mg} \mathrm{L}^{-1}\right)$ & $\begin{array}{l}1 \\
2 \\
3\end{array}$ & $\begin{array}{l}0.012 \pm 0.009^{\mathrm{a}} \\
0.010 \pm 0.001^{\mathrm{a}} \\
0.003 \pm 0.002^{\mathrm{b}}\end{array}$ & $\begin{array}{l}0.063 \pm 0.007^{\mathrm{b}} \\
0.015 \pm 0.001^{\mathrm{b}} \\
0.003 \pm 0.002^{\mathrm{a}}\end{array}$ & 0.01 & 0.00 \\
\hline Total Kjeldahl nitrogen $\left(\mathrm{mg} \mathrm{kg}^{-1}\right)$ & $\begin{array}{l}1 \\
2 \\
3\end{array}$ & $\begin{array}{l}0.4 \pm 0.1^{\mathrm{a}} \\
0.4 \pm 0.1^{\mathrm{a}} \\
0.4 \pm 0.1^{\mathrm{a}}\end{array}$ & $\begin{array}{l}1.4 \pm 0.3^{\mathrm{b}} \\
1.3 \pm 0.6^{\mathrm{b}} \\
0.66 \pm 0.3^{\mathrm{a}}\end{array}$ & 0.00 & 0.03 \\
\hline $\mathrm{P}_{-} \mathrm{PO}_{4}^{-}\left(\mathrm{mg} \mathrm{L}^{-1}\right)$ & $\begin{array}{l}1 \\
2 \\
3\end{array}$ & $\begin{array}{l}0.09 \pm 0.03^{\mathrm{a}} \\
0.10 \pm 0.01^{\mathrm{a}} \\
0.08 \pm 0.03^{\mathrm{a}}\end{array}$ & $\begin{array}{l}0.16 \pm 0.04^{\mathrm{b}} \\
0.13 \pm 0.01^{\mathrm{b}} \\
0.06 \pm 0.02^{\mathrm{a}}\end{array}$ & 0.00 & 0.00 \\
\hline Total P (mg L $\left.{ }^{-1}\right)$ & $\begin{array}{l}1 \\
2 \\
3\end{array}$ & $\begin{array}{l}0.26 \pm 0.12^{\mathrm{a}} \\
0.20 \pm 0.03^{\mathrm{a}} \\
0.13 \pm 0.01^{\mathrm{a}}\end{array}$ & $\begin{array}{l}0.23 \pm 0.07^{\mathrm{a}} \\
0.24 \pm 0.08^{\mathrm{a}} \\
0.16 \pm 0.01^{\mathrm{b}}\end{array}$ & 0.00 & 0.00 \\
\hline TRIX index & $\begin{array}{l}1 \\
2 \\
3\end{array}$ & $\begin{array}{l}2.9 \pm 0.3^{\mathrm{a}} \\
2.2 \pm 0.2^{\mathrm{a}} \\
2.5 \pm 0.2^{\mathrm{a}}\end{array}$ & $\begin{array}{l}3.7 \pm 0.4^{\mathrm{b}} \\
2.6 \pm 0.2^{\mathrm{b}} \\
2.4 \pm 0.2^{\mathrm{a}}\end{array}$ & 0.00 & 0.00 \\
\hline
\end{tabular}

Different letters in the same row indicate significant differences for that sampling $(P<0.05)$. 
Table 3. Water and sediment quality parameters $( \pm \mathrm{SD})$ recorded at different distances from the discharge point in the impacted and nonimpacted areas when shrimp farms had ceased operations (survey 1).

Tabla 3. Parámetros de la calidad del agua y el sedimento $( \pm \mathrm{DE})$ registrados a las diferentes distancias del punto de descarga en la zona impactada y la no impactada cuando las granjas finalizaron sus operaciones (muestreo 1).

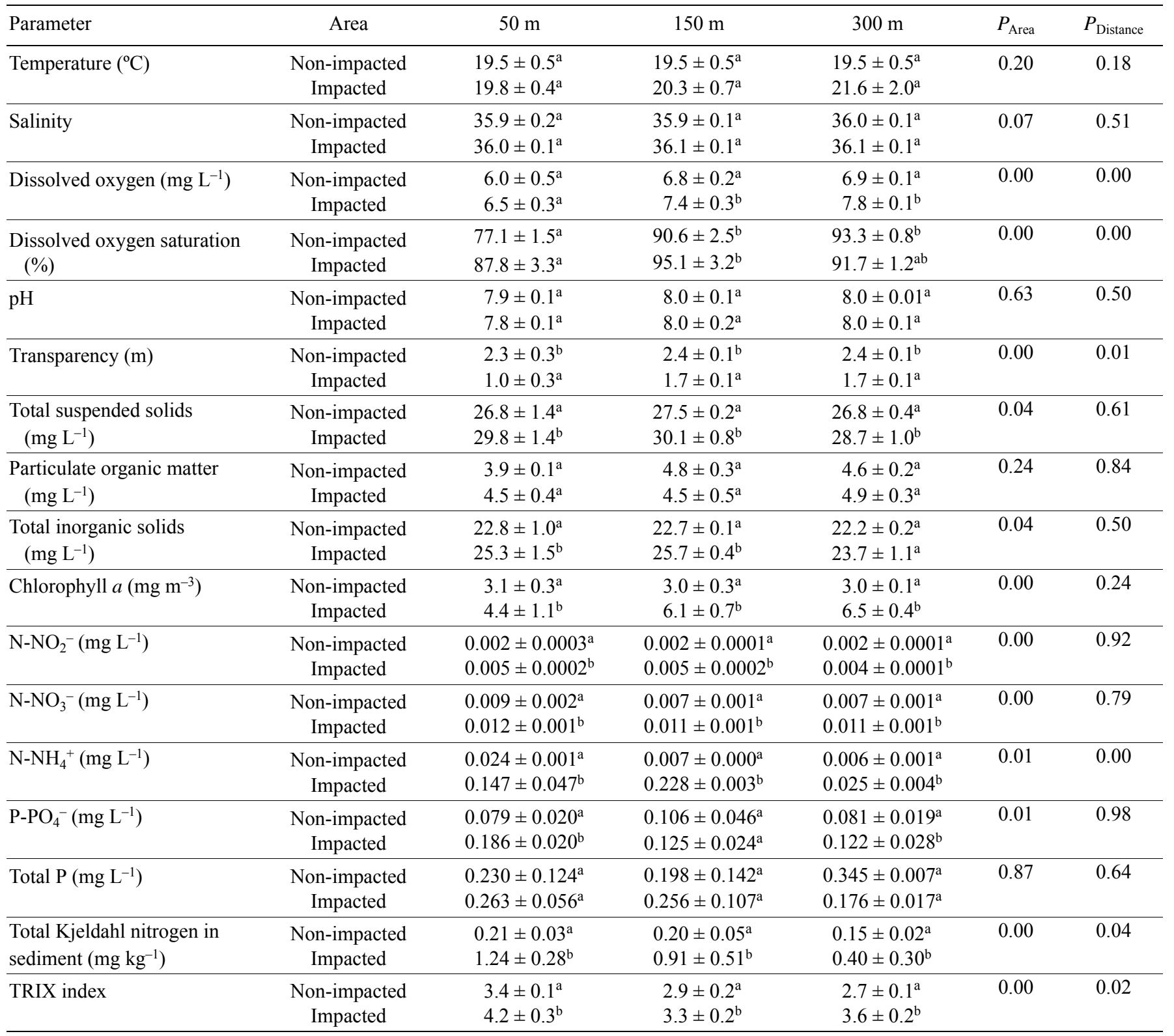

Different letters in the same row indicate significant differences for that sampling $(P<0.05)$.

In survey 3 , when the farms had halted operations or prematurely harvested (table 5), most of the parameters were statistically similar in both areas regardless of the distance. TSS was significantly higher in the non-impacted area at all three distances $(50,150$, and $300 \mathrm{~m})$. Particulate organic matter, TIS, and $\mathrm{P}_{-} \mathrm{PO}_{4}{ }^{-}$were higher in the non-impacted area in the first $150 \mathrm{~m}$ from shore. A decline in water transparency and an increase in TKN concentrations in sediments were the only negative effects recorded in the first $150 \mathrm{~m}$ of the impacted area. los indicadores ambientales de la calidad del agua y de los sedimentos. Ha sido ampliamente documentado que los componentes de los efluentes de granjas acuícolas que pueden causar mayor impacto sobre el ambiente son los sólidos suspendidos orgánicos e inorgánicos (producto del alimento no consumido, restos de organismos, comunidades microbianas y sedimento resuspendido especialmente durante la cosecha; McIntosh y Fitzsimmons 2003, Constanzo et al. 2004, Thuyet et al. 2012), así como los compuestos nitrogenados que pueden llegar a ser tóxicos para las comunidades que habitan los 
Table 4. Water and sediment quality parameters $( \pm \mathrm{SD})$ recorded at different distances from the discharge point in the impacted and nonimpacted areas when shrimp farms had iniated operations (survey 2).

Tabla 4. Parámetros de la calidad del agua y el sedimento $( \pm \mathrm{DE})$ registrados a las diferentes distancias del punto de descarga en la zona impactada y la no impactada cuando las granjas inciaron sus operaciones (muestreo 2).

\begin{tabular}{|c|c|c|c|c|c|c|}
\hline Parameter & Area & $50 \mathrm{~m}$ & $150 \mathrm{~m}$ & $300 \mathrm{~m}$ & $P_{\text {Area }}$ & $P_{\text {Distance }}$ \\
\hline \multirow[t]{2}{*}{ Temperature $\left({ }^{\circ} \mathrm{C}\right)$} & Non-impacted & $22.6 \pm 0.1^{\mathrm{a}}$ & $22.7 \pm 0.1^{\mathrm{b}}$ & $22.7 \pm 0.1^{\mathrm{b}}$ & 0.00 & 0.16 \\
\hline & Impacted & $22.5 \pm 0.2^{\mathrm{a}}$ & $21.8 \pm 0.2^{\mathrm{a}}$ & $21.7 \pm 0.1^{\mathrm{a}}$ & & \\
\hline \multirow[t]{2}{*}{ Salinity } & Non-impacted & $35.0 \pm 0.1^{\mathrm{a}}$ & $34.6 \pm 0.4^{\mathrm{a}}$ & $34.8 \pm 0.1^{\mathrm{a}}$ & 0.77 & 0.91 \\
\hline & Impacted & $34.8 \pm 0.1^{\mathrm{a}}$ & $34.6 \pm 0.4^{\mathrm{a}}$ & $35.0 \pm 0.2^{\mathrm{a}}$ & & \\
\hline \multirow[t]{2}{*}{ Dissolved oxygen $\left(\mathrm{mg} \mathrm{L}^{-1}\right)$} & Non-impacted & $9.0 \pm 0.1^{\mathrm{a}}$ & $9.3 \pm 0.3^{b}$ & $10.0 \pm 0.2^{b}$ & 0.00 & 0.32 \\
\hline & Impacted & $9.2 \pm 0.4^{\mathrm{a}}$ & $8.9 \pm 0.1^{\mathrm{a}}$ & $8.5 \pm 0.1^{\mathrm{a}}$ & & \\
\hline \multirow{2}{*}{$\begin{array}{l}\text { Dissolved oxygen saturation } \\
(\%)\end{array}$} & Non-impacted & $103.7 \pm 2.1^{\mathrm{a}}$ & $108.7 \pm 2.5^{\mathrm{b}}$ & $115.3 \pm 1.2^{b}$ & 0.00 & 0.65 \\
\hline & Impacted & $106.3 \pm 4.4^{\mathrm{a}}$ & $102.4 \pm 0.6^{\mathrm{a}}$ & $96.1 \pm 1.0^{\mathrm{a}}$ & & \\
\hline \multirow[t]{2}{*}{$\mathrm{pH}$} & Non-impacted & $8.2 \pm 0.1^{\mathrm{a}}$ & $8.2 \pm 0.1^{\mathrm{a}}$ & $8.2 \pm 0.1^{\mathrm{a}}$ & 0.90 & 0.92 \\
\hline & Impacted & $8.2 \pm 0.0^{\mathrm{a}}$ & $8.2 \pm 0.0^{\mathrm{a}}$ & $8.2 \pm 0.0^{\mathrm{a}}$ & & \\
\hline \multirow[t]{2}{*}{ Transparency (m) } & Non-impacted & $2.01 \pm 0.06^{\mathrm{b}}$ & $2.4 \pm 0.17^{b}$ & $2.6 \pm 0.2^{\mathrm{a}}$ & 0.03 & 0.00 \\
\hline & Impacted & $1.07 \pm 0.12^{\mathrm{a}}$ & $2.0 \pm 0.0^{\mathrm{ab}}$ & $3.0 \pm 0.0^{\mathrm{b}}$ & & \\
\hline \multirow{2}{*}{$\begin{array}{l}\text { Total suspended solids } \\
\left(\mathrm{mg} \mathrm{L}^{-1}\right)\end{array}$} & Non-impacted & $25.1 \pm 2.9^{\mathrm{a}}$ & $21.8 \pm 1.5^{\mathrm{a}}$ & $20.9 \pm 0.3^{\mathrm{a}}$ & 0.04 & 0.51 \\
\hline & Impacted & $36.2 \pm 2.7^{b}$ & $30.5 \pm 1.3^{b}$ & $28.1 \pm 0.1^{\mathrm{b}}$ & & \\
\hline \multirow{2}{*}{$\begin{array}{l}\text { Particulate organic matter } \\
\left(\mathrm{mg} \mathrm{L}^{-1}\right)\end{array}$} & Non-impacted & $4.0 \pm 0.7^{\mathrm{a}}$ & $3.2 \pm 0.2^{\mathrm{a}}$ & $3.2 \pm 0.1^{\mathrm{a}}$ & 0.12 & 0.52 \\
\hline & Impacted & $4.6 \pm 0.8^{\mathrm{a}}$ & $4.4 \pm 0.2^{\mathrm{a}}$ & $4.0 \pm 0.1^{\mathrm{a}}$ & & \\
\hline \multirow{2}{*}{$\begin{array}{l}\text { Total inorganic solids } \\
\left(\mathrm{mg} \mathrm{L}^{-1}\right)\end{array}$} & Non-impacted & $21.1 \pm 2.4^{\mathrm{a}}$ & $18.6 \pm 1.4^{\mathrm{a}}$ & $17.7 \pm 0.4^{\mathrm{a}}$ & 0.04 & 0.02 \\
\hline & Impacted & $31.6 \pm 1.9^{\mathrm{b}}$ & $26.1 \pm 1.0^{\mathrm{b}}$ & $24.1 \pm 0.2^{\mathrm{a}}$ & & \\
\hline \multirow[t]{2}{*}{ Chlorophyll $a\left(\mathrm{mg} \mathrm{m}^{-3}\right)$} & Non-impacted & $1.1 \pm 0.1^{\mathrm{a}}$ & $1.0 \pm 0.1^{\mathrm{a}}$ & $1.1 \pm 0.1^{\mathrm{a}}$ & 0.03 & 0.56 \\
\hline & Impacted & $5.0 \pm 0.9^{b}$ & $2.4 \pm 0.2^{\mathrm{b}}$ & $1.8 \pm 0.1^{\mathrm{b}}$ & & \\
\hline \multirow[t]{2}{*}{$\mathrm{N}-\mathrm{NO}_{2}^{-}\left(\mathrm{mg} \mathrm{L}^{-1}\right)$} & Non-impacted & $0.005 \pm 0.0002^{\mathrm{a}}$ & $0.011 \pm 0.0007^{b}$ & $0.011 \pm 0.0006^{\mathrm{b}}$ & 0.00 & 0.21 \\
\hline & Impacted & $0.012 \pm 0.0004^{b}$ & $0.005 \pm 0.0001^{\mathrm{a}}$ & $0.005 \pm 0.0005^{\mathrm{a}}$ & & \\
\hline \multirow[t]{2}{*}{$\mathrm{N}-\mathrm{NO}_{3}^{-}\left(\mathrm{mg} \mathrm{L}^{-1}\right)$} & Non-impacted & $0.014 \pm 0.0017^{\mathrm{a}}$ & $0.013 \pm 0.0004^{\mathrm{a}}$ & $0.014 \pm 0.0008^{\mathrm{a}}$ & 0.00 & 0.07 \\
\hline & Impacted & $0.018 \pm 0.0012^{\mathrm{b}}$ & $0.018 \pm 0.0008^{b}$ & $0.021 \pm 0.0006^{\mathrm{b}}$ & & \\
\hline \multirow[t]{2}{*}{$\mathrm{N}-\mathrm{NH}_{4}^{+}\left(\mathrm{mg} \mathrm{L}^{-1}\right)$} & Non-impacted & $0.010 \pm 0.0009^{\mathrm{a}}$ & $0.009 \pm 0.0001^{\mathrm{a}}$ & $0.010 \pm 0.0006^{\mathrm{a}}$ & 0.00 & 0.62 \\
\hline & Impacted & $0.014 \pm 0.0022^{\mathrm{b}}$ & $0.013 \pm 0.0009^{b}$ & $0.016 \pm 0.0011^{\mathrm{b}}$ & & \\
\hline \multirow[t]{2}{*}{$\mathrm{P}_{-} \mathrm{PO}_{4}^{-}\left(\mathrm{mg} \mathrm{L}^{-1}\right)$} & Non-impacted & $0.098 \pm 0.004^{\mathrm{a}}$ & $0.090 \pm 0.0074^{\mathrm{a}}$ & $0.104 \pm 0.0107^{\mathrm{a}}$ & 0.01 & 0.47 \\
\hline & Impacted & $0.124 \pm 0.013^{b}$ & $0.114 \pm 0.004^{\mathrm{b}}$ & $0.140 \pm 0.010^{\mathrm{b}}$ & & \\
\hline \multirow[t]{2}{*}{ Total P $\left(\mathrm{mg} \mathrm{L}^{-1}\right)$} & Non-impacted & $0.189 \pm 0.032^{\mathrm{a}}$ & $0.177 \pm 0.016^{\mathrm{a}}$ & $0.232 \pm 0.031^{\mathrm{a}}$ & 0.21 & 0.59 \\
\hline & Impacted & $0.221 \pm 0.016^{\mathrm{a}}$ & $0.250 \pm 0.014^{\mathrm{a}}$ & $0.242 \pm 0.026^{\mathrm{a}}$ & & \\
\hline \multirow{2}{*}{$\begin{array}{l}\text { Total Kjeldahl nitrogen in } \\
\text { sediment }\left(\mathrm{mg} \mathrm{kg}^{-1}\right)\end{array}$} & Non-impacted & $0.41 \pm 0.19^{\mathrm{a}}$ & $0.39 \pm 0.15^{\mathrm{a}}$ & $0.38 \pm 0.17^{\mathrm{a}}$ & 0.00 & 0.02 \\
\hline & Impacted & $1.21 \pm 0.41^{\mathrm{b}}$ & $1.22 \pm 0.33^{\mathrm{b}}$ & $0.70 \pm 0.32^{\mathrm{a}}$ & & \\
\hline \multirow[t]{2}{*}{ TRIX index } & Non-impacted & $2.5 \pm 0.2^{\mathrm{a}}$ & $2.0 \pm 0.2^{\mathrm{a}}$ & $2.2 \pm 0.1^{\mathrm{a}}$ & 0.08 & 0.21 \\
\hline & Impacted & $2.6 \pm 0.1^{\mathrm{a}}$ & $2.4 \pm 0.3^{\mathrm{a}}$ & $2.4 \pm 0.2^{\mathrm{a}}$ & & \\
\hline
\end{tabular}

Different letters in the same row indicate significant differences for that sampling $(P<0.05)$.

\section{Discussion}

Our results show that the shrimp farm effluents have a negative effect on most of the selected environmental indicators of water and sediment quality. It has been well documented that the components in the shrimp farm effluents that have a greater impact on the environment are organic and inorganic suspended solids (resulting from uneaten food, remains of organisms, microbial communities, and resuspended sediments especially during harvesting; McIntosh and Fitzsimmons 2003, Constanzo et al. 2004, Thuyet et al. ecosistemas receptores (Martínez-Córdova et al. 2009). El incremento en los niveles de clorofila $a$ en la zona impactada revela un incremento en la productividad primaria debido al aumento en las concentraciones de metabolitos nitrogenados y fosforados, lo cual podría representar un riesgo de desbalance trófico si estos niveles llegan a concentraciones más elevadas. Un estudio paralelo (datos en preparación) revela cambios significativos en la abundancia y composición de fitoplancton entre la zona impactada y la no impactada.

Además de los metabolitos nitrogenados y sólidos suspendidos, el incremento en el índice TRIX para la zona 
Table 5. Water and sediment quality parameters $( \pm \mathrm{SD})$ recorded at different distances from the discharge point in the impacted and nonimpacted areas when shrimp farmers resorted to early harvesting (survey 3 ).

Tabla 5. Parámetros de la calidad del agua y el sedimento $( \pm \mathrm{DE})$ registrados a las diferentes distancias del punto de descarga en la zona impactada y la no impactada cuando las granjas iniciaron las cosechas prematuras (muestreo 3 ).

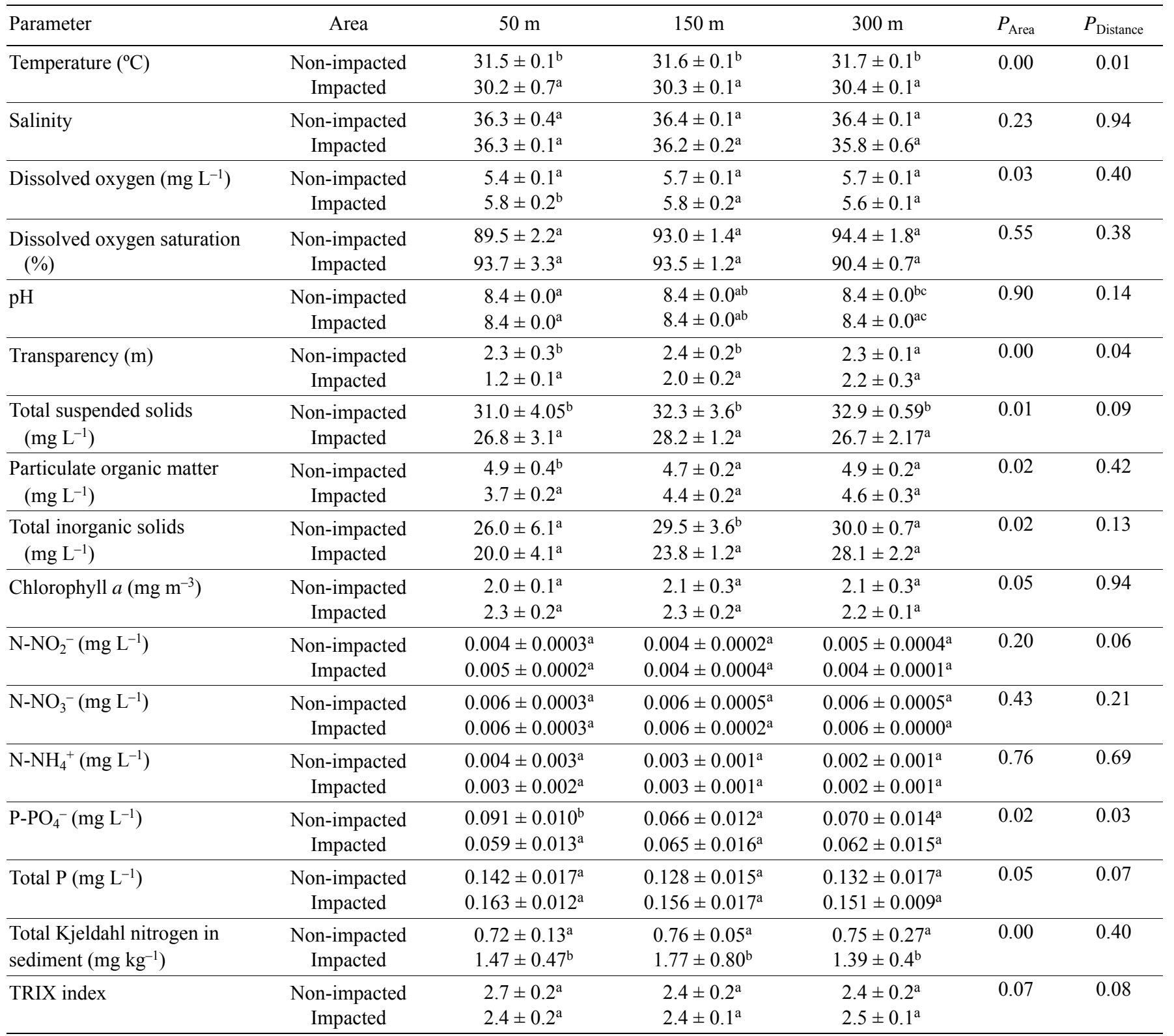

Different letters in the same row indicate significant differences for that sampling $(P<0.05)$.

2012) and nitrogen compounds that can become toxic for the communities inhabiting the receiving ecosystems (MartínezCórdova et al. 2009). The increased chlorophyll $a$ levels in the impacted area indicate an increase in primary productivity due to an increase in the concentrations of nitrogen and phosphorus metabolites, which could pose a risk of trophic inbalance if these levels increase. A parallel study (as yet unpublished) reveals significant changes in phytoplankton abundance and composition between the impacted and nonimpacted areas. impactada sugiere que el abastecimiento de materia orgánica a través de los efluentes es superior a la capacidad de asimilación del medio. Se observó que hacia el final del ciclo de cultivo (muestreo 1), el estado trófico del cuerpo de agua receptor pasó de ser oligotrófico a mesotrófico. Este efecto puede asociarse con un alto grado de certeza a la descarga de efluentes, ya que en la zona no impactada tanto el índice TRIX como la mayoría de los parámetros (SST, SIT, clorofila $a, \mathrm{~N}^{-\mathrm{NO}_{2}}{ }^{-}, \mathrm{N}-\mathrm{NO}_{3}^{-}, \mathrm{N}^{-} \mathrm{NH}_{4}^{+}, \mathrm{P}^{-} \mathrm{PO}_{4}^{-}, \mathrm{NTK}$ y transparencia) permanecieron comparativamente bajos. 
In addition to the nitrogen metabolites and suspended solids, the increase in the TRIX index for the impacted area suggests that the input of organic matter via the effluents exceeds the assimilative capacity of the environment. When the shrimp farms ceased operations (survey 1), the trophic state of the receiving water changed from oligotrophic to mesotrophic. This effect can almost certainly be associated with the effluent discharges, since in the non-impacted area, the TRIX index as well as most of the parameters (TSS, TIS, chlorophyll $a, \mathrm{~N}_{-} \mathrm{NO}_{2}^{-}, \mathrm{N}^{-\mathrm{NO}_{3}}{ }^{-}, \mathrm{N}-\mathrm{NH}_{4}^{+}, \mathrm{P}_{-} \mathrm{PO}_{4}^{-}, \mathrm{TKN}$, and transparency) remained comparatively low.

A negative effect on the parameters examined was only observed when the farms had ceased operations (survey 1) and inititated operations (survey 2), but not during the early harvest period (survey 3). An explanation for this is that by the end of the culture cycle, the farms had discharged effluents for over seven months and the receiving system was overloaded. On the other hand, in survey 3, most of the monitored parameters were similar in the impacted and nonimpacted areas, and this can be attributed to the fact that during the months of recess the environment did not receive effluents and the excess organic matter and nutrients may have been assimilated. Moreover, when survey 3 was conducted, the farms had only been operating for two months and the supply of food had not yet reached its peak, and the environment still had the capacity to assimilate the organic and inorganic loads. Hedges et al. (1997) analyzed the capacity of the marine environment to assimilate and/or decompose particulate and dissolved organic matter of terrestrial origin, and argumented that this implies a complex mechanism of transport, rapid oxidation, and other transformations.

Another explanation for the recovery of the environment is that, particularly during the 2013 cycle, the culture area and consequently the volume of effluent discharged decreased considerably relative to previous cycles, mainly because of the appearance of epizootic diseases such as the sudden death syndrome. Some farms were thus unable to complete the cycle and effluents were not discharged into the environment.

During surveys 1 and 2, the negative impact was stronger at the distance of $50 \mathrm{~m}$ from the discharge point. Most of the parameters, however, were negatively affected at all three distances. This suggests that the effluents have greater impact in an area of around $8000 \mathrm{~m}^{2}$, though negative effects can, to a lesser extent, be observed in an area of approximately $282,600 \mathrm{~m}^{2}$. Nonetheless, the results obtained in survey 3 can be an indication of the considerable capacity of the environment to recover, and the temporary suspension of shrimp farming operations can be beneficial for the effluentreceiving waters.

In the case of TSS, the values recorded were below the maximum permissible limit for aquaculture effluents, which is around $100 \mathrm{mg} \mathrm{L}^{-1}$ internationally (Boyd and Gautier 2000) and $175 \mathrm{mg} \mathrm{L}^{-1}$ nationally (Official Mexican Norm NOM-001-ECOL-1996). Nonetheless, the constant discharge
El efecto negativo sobre los parámetros examinados se observó solamente cuando las granjas estaban terminando (muestreo 1) e iniciando (muestreo 2) sus operaciones, pero no en el momento en que las granjas realizaron las cosechas prematuras (muestreo 3). Lo anterior podría asociarse al hecho de que hacia el final del ciclo de cultivo, las granjas habían descargado efluentes al medio por más de siete meses, lo cual implica que el sistema receptor se encontraba sobrecargado. Por otro lado, el hecho de que en el muestreo 3 la mayoría de los parámetros monitoreados fueron similares en la zona impactada y en la no impactada podría deberse a que durante las cosechas prematuras el medio no recibió efluentes, y pudo haber ocurrido un proceso de asimilación del exceso de materia orgánica y nutrientes. Además, cuando se llevó a cabo el último muestreo, las granjas tenían apenas dos meses en operación y todavía no alcanzaban el máximo de suministro de alimento; por lo tanto, probablemente el medio estaba todavía en condiciones de asimilar la carga orgánica e inorgánica. Hedges et al. (1997) demostraron la capacidad del ambiente oceánico para asimilar y/o descomponer la materia orgánica particulada y disuelta de origen terrestre, y argumentaron que esto implica un mecanismo complejo de transporte, oxidación rápida y otras transformaciones.

Otra de las razones de la recuperación del medio se debió a que, en particular durante el ciclo de 2013, la superficie cultivada y consecuentemente el volumen de efluentes disminuyeron significativamente respecto a los ciclos anteriores, principalmente debido a la aparición de epizootias como el síndrome de la muerte temprana. Por ende, algunas de las granjas no alcanzaron a terminar su ciclo y por lo tanto no descargaron efluentes al medio.

Durante los muestreos 1 y 2, el impacto negativo fue más acentuado a $50 \mathrm{~m}$ del punto de la descarga; sin embargo, la mayoría de los parámetros fueron afectados negativamente a todas las distancias. Esto sugiere que los efluentes tienen mayor impacto sobre un área de alrededor de $8000 \mathrm{~m}^{2}$, aunque se pueden observar efectos negativos, en menor medida, dentro de un área aproximada de $282,600 \mathrm{~m}^{2}$. No obstante, los resultados obtenidos en el muestreo 3 podrían representar evidencia de una considerable capacidad de recuperación del medio y de que los recesos operativos de las granjas resultan benéficiosos para las aguas receptoras de los efluentes.

En el caso de los SST, los valores registrados en todos los muestreos estuvieron por debajo de los niveles máximos recomendados internacionalmente (alrededor de $100 \mathrm{mg} \mathrm{L}^{-1}$, Boyd y Gautier 2000) y de los límites permisibles por la Norma Oficial Mexicana (175 mg L ${ }^{-1}$, NOM-001-ECOL1996) para efluentes acuícolas. No obstante, se pudo apreciar que la descarga constante de efluentes tiene el potencial de modificar el nivel trófico del ecosistema, al menos en el área adyacente al punto de descarga.

Las concentraciones de nitrógeno inorgánico total $(\mathrm{N}-$

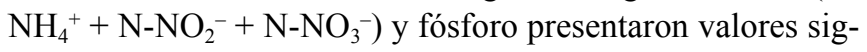
nificativamente mayores en la zona impactada que en la no impactada, aunque los niveles no llegaron a ser considerados 
of effluents has the potential to modify the trophic level of the ecosystem, at least in the area adjacent to the discharge point.

The concentrations of total inorganic nitrogen $\left(\mathrm{N}^{-N_{4}}{ }_{4}^{+}+\right.$ $\mathrm{N}-\mathrm{NO}_{2}{ }^{-}+\mathrm{N}^{-} \mathrm{NO}_{3}{ }^{-}$) and phosphorus were significantly higher in the impacted area but did not reach unacceptable levels (Boyd 2003, Sará 2007). Official Mexican Norm NOM-001SEMARNAT-1996 does not establish limits for total nitrogen and phosphorus in coastal waters, but does establish limits of 15 and $5 \mathrm{mg} \mathrm{L}^{-1}$ (monthly average) for total nitrogen and total phosphorus, respectively, in estuaries. Even though the nitrogen and phosphorus values were below these limits, they were high enough to significantly increase the natural productivity of the impacted area. The chlorophyll $a$ levels correspond to a moderately productive ecosystem, typical of coastal areas with important nutrient inputs, and even though they do not really represent an environmental problem, they should not be discarded as a future risk factor.

In regard to sediment quality, the organic matter values were very low in both areas in surveys 1 and 2 . The TKN concentrations were significantly higher in the impacted area, most likely because of the accumulation of particulate organic matter from the effluent. Biao et al. (2013) found that the concentration of organic nitrogen in sediments of an estuary receiving shrimp farm effluents increased from $5 \%$ to $30 \%$ over the past 40 years. The values reported to date are $0.07 \%$ (700 mg kg-1), lower than those recorded in the present study. Hence, the fact that higher TKN values have been recorded for an effluent discharging into the open sea and affecting the trophic state of the environment is a matter that requires proper attention.

Our findings coincide with those reported for Guaymas Bay (Elizalde-Servín 2009, Osuna-Ramírez 2010), Kunkaak Bay (Montijo-Angulo 2011), and San Francisco Bay (Rosales-Flores 2012) in Sonora, which also present oligotrophic to mesotrophic conditions and high water quality. Likewise, Reynaga-Franco (2009) examined the behavior of water quality parameters and the trophic state of three semiarid coastal lagoons of Sonora and obtained TRIX values of $<3.0$ units, indicating an oligotrophic state.

Barraza-Guardado et al. (2013) studied the influence of shrimp farm discharges on Kino Bay and a nearby coastal lagoon (Sonora) and reported TSS values of $233.3 \mathrm{mg} \mathrm{L}^{-1}$ in the effluent, $56.2 \mathrm{mg} \mathrm{L}^{-1}$ in the bay, and $52.7 \mathrm{mg} \mathrm{L}^{-1}$ in the lagoon. These values are all higher than those obtained in the present study, most probably because the volume of the effluent was higher since the aquaculture park in this case was one of greater production capacity.

In summary, the effluent discharged from shrimp farms has a negative impact on water and sediment quality of the receiving ecosystem. In this study, however, the impact was less than expected. This can be attributed, among other reasons, to the temporary suspension of shrimp farming operations, which allows the environment to assimilate the excess organic and inorganic matter. The levels of the water como contaminantes (Boyd 2003, Sará 2007). La Norma Oficial Mexicana (NOM-001-SEMARNAT-1996) no establece límites de nitrógeno y fósforo total para aguas costeras, pero para estuarios establece un límite máximo (como promedio mensual) de $15 \mathrm{mg} \mathrm{L}^{-1}$ para nitrógeno total y de $5 \mathrm{mg} \mathrm{L}^{-1}$ para fósforo total. No obstante que los niveles de nitrógeno y fósforo estuvieron por debajo de la norma, fueron suficientes como para incrementar de manera significativa la productividad natural de la zona impactada. Los niveles de clorofila $a$ corresponden a un ecosistema moderadamente productivo, típico de zonas costeras con aportes importantes de nutrientes, y aunque es poco probable que represente algún problema de impacto ambiental, no puede descartarse como un factor de riesgo.

Con respecto a la calidad del sedimento, los valores de materia orgánica fueron muy bajos en ambas zonas en los dos primeros muestreos. Las concentraciones de NTK fueron significativamente más altas en la zona impactada, lo cual pudiera atribuirse a la acumulación del material orgánico particulado proveniente del efluente. Biao et al. (2013) encontraron que la concentración de nitrógeno orgánico en los sedimentos de un estuario receptor de efluentes de granjas camaronícolas aumentó del $5 \%$ al $30 \%$ en los últimos 40 años. Los valores documentados a la fecha son de $0.07 \%$ (700 $\mathrm{mg} \mathrm{kg}^{-1}$ ), menores que los que se registraron en el presente estudio. Considerando lo anterior, el hecho de que una descarga de efluentes hacia el mar abierto ocasione valores altos de NTK y tenga un efecto sobre el nivel trófico del medio es un asunto al cual se le debe de dar la debida importancia.

Los resultados obtenidos en este estudio son coincidentes con los registrados para bahía de Guaymas (Elizalde-Servín 2009, Osuna-Ramírez 2010), bahía Kunkaak (MontijoAngulo 2011) y bahía San Francisco (Rosales-Flores 2012) en Sonora, los cuales también mantienen condiciones de oligotrofia a mesotrofia y una alta calidad del agua. Asimismo, nuestros resultados son consistentes con los de Reynaga-Franco (2009), quienes analizaron los parámetros de la calidad del agua y el estado trófico de tres lagunas costeras semiáridas de Sonora y registraron valores del índice TRIX de $<3.0$ unidades en primavera y en verano, lo cual indica un estado oligotrófico.

Barraza-Guardado et al. (2013), en un estudio sobre la influencia de descargas camaronícolas en bahía Kino y una laguna costera aledaña (Sonora), obtuvieron valores de SST de $233.3 \mathrm{mg} \mathrm{L}^{-1}$ en el efluente, $56.2 \mathrm{mg} \mathrm{L}^{-1}$ en la bahía y $52.7 \mathrm{mg} \mathrm{L}^{-1}$ en la laguna. En todos los casos, estos valores son mayores que los obtenidos en el presente estudio, presumiblemente debido a que el volumen de los efluentes que estos autores analizaron fue mayor porque provinieron de un parque acuícola con mayor capacidad de producción.

En resumen, la descarga de efluentes procedentes de la camaronicultura tiene un impacto negativo sobre la calidad del agua y del sedimento del ecosistema receptor. En este estudio, sin embargo, el impacto fue menor al esperado. Esto 
and sediment quality parameters in the impacted area did not exceed the limits established by Mexican and international norms, but if more farms are eventually installed or if the capacity of those already installed increases, they may rise and pose a risk in the future.

Further monitoring studies are needed and should consider other aspects and tools that will help to better explain the true effect of effluents on the coastal zone, such as dispersion modelling (Symonds 2011) and the use of tracers (Mee and Readman 1993) to examine the pathways and destiny of pollutants.

\section{ACKNOWLEDGMENTS}

This study was funded by the Instituto Nacional de Pesca (INAPESCA) and Coordinadora Nacional de las Fundaciones Produce, AC (COFUPRO, Mexico).

English translation by Christine Harris.

\section{REFERENCES}

[APHA] American Public Health Association. 1992. Standard Methods for the Examination of Water and Wastewater. Clescer L, Greenberg AE, and Trussell RR (eds.), 17th ed. Washington, DC, pp 9-61.

[APHA] American Public Health Association. 1998. Standard Methods for the Examination of Water and Wastewater. American Public Health Association, Washington, DC, 1268 pp.

Barraza-Guardado RH, Arreola-Lizárraga JA, López-Torres MA, Casillas-Hernández R, Miranda-Baeza A, Magallón-Barrajas F, Ibarra-Gámez C. 2013. Effluents of shrimp farms and it influence on the coastal ecosystems of Bahía de Kino, Mexico. Sci. World J., article ID 306370, 8 pp.

Biao H, Wua Y, Unger D, Dua J, Herbeck LS, Zhang J. 2013. Impact of the conversion of mangroves into aquaculture ponds on the sedimentary organic matter composition in a tidal flat estuary (Hainan Island, China). Cont. Shelf Res. 57: 82-91.

Boyd CE. 2003. Guidelines for aquaculture effluent management at the farm-level. Aquaculture 226: 101-112.

Boyd CE, Gautier D. 2000. Effluent composition and water quality standards. Glob. Aquacult. Adv. 3: 61-66.

Casillas-Hernández R, Magallón-Barajas F, Portillo CG, Páez-Osuna F. 2006. Nutrient mass balance in semi-intensive shrimp ponds from Sonora, Mexico, using two feeding strategies: trays and mechanical dispersal. Aquaculture 258: 289-298.

[CONAPESCA] Comisión Nacional de Acuacultura y Pesca. 2011. Estadístico de pesca y acuacultura. Comisión Nacional de Acuacultura y Pesca, Mazatlán, Sinaloa, México, 305 pp.

Conover WJ. 1980. Practical Nonparametric Statistics. Wiley, New York, $583 \mathrm{pp}$.

Costanzo SD, O'Donohue MJ, Dennison WC. 2004. Assessing the influence and distribution of shrimp pond effluent in a tidal mangrove creek in north-east Australia. Mar. Pollut. Bull. 48: 514-525.

Dell'Anno A, Mei ML, Pusceddu A, Danovaro R. 2002. Assessing the trophic state and eutrophication of coastal marine systems: A new approach based on the biochemical composition of sediment organic matter. Mar. Pollut. Bull. 44: 611-622.

Dos Santos Simoes F, Moreira AB, Bisinoti MC, NobreGimenez SM, Santos Yabe MJ. 2008. Water quality index as a simple se puede atribuir, entre otras cosas, al receso de cinco meses que llevan a cabo las granjas camaronícolas, lo cual permite la asimilación del exceso de materia orgánica e inorgánica. Aunque los niveles de los parámetros de la calidad del agua y del sedimento en la zona impactada no alcanzaron los límites máximos establecidos por las normas mexicanas e internacionales, su alteración podría considerarse como un indicador de riesgo a largo plazo si eventualmente se instalan otras granjas contiguas o se aumenta la capacidad de las ya instaladas.

Es importante que se sigan realizando este tipo de estudios considerando otros factores, como los modelos de dispersión de los contaminantes (Symonds 2011), uso de trazadores (Mee y Readman 1993) para ver las rutas y el destino de los mismos, y aspectos adicionales que ayuden a explicar de mejor manera el efecto real de las descargas contaminantes sobre la zona costera.

\section{Agradecimientos}

Deseamos agradecer el apoyo financiero por parte del Instituto Nacional de Pesca (INAPESCA) y la Coordinadora Nacional de las Fundaciones Produce, AC (COFUPRO, México).

indicator of aquaculture effects on aquatic bodies. Ecol. Indicat. 8: 476-484.

Elizalde-Servín CI. 2009. Evaluación de la calidad del agua de la bahía de Guaymas, Sonora, con y sin aportes de aguas residuales. México. MSc thesis, Instituto Tecnológico de Guaymas, Sonora, Mexico, $51 \mathrm{pp}$.

[FAO] Food and Agriculture Organization. 2012. The State of World Fisheries and Aquaculture. Food and Agriculture Organization, Rome, Italy.

Hakanson L, Boulion V. 2002. The Lake Foodweb: Modelling Predation and Abiotic/biotic Interactions. Backhuys Publishers, Leiden, $344 \mathrm{pp}$.

Hedges JI, Keil RG, Benner R. 1997. What happens to terrestrial organic matter in the ocean? Org. Geochem. 27: 195-212.

Kern K. 2011. Governance for sustainable development in the Baltic Sea region. J. Baltic Stud. 42: 21-35.

Lluch-Cota SE. 2000. Coastal upwelling in the eastern Gulf of California. Oceanol. Acta 23: 731-740.

Lundin LC. 2000. The Waterscape. Sustainable water management in the Baltic Sea basin. Baltic Univ. Prog., Uppsala University, Uppsala.

Martínez-Córdova LR, Martínez-Porchas M, Cortés-Jacinto E. 2009. Camaronicultura mexicana y mundial: ¿Actividad sustentable o industria contaminante? Rev. Int. Contam. Ambient. 25: 181-196.

Martínez-Porchas M, Martínez-Córdova LR. 2012. World aquaculture: Environmental impacts and troubleshooting alternatives. The Scientific World Journal, article ID 389623, 9 pp.

Mee LD, Readman JW. 1993. Técnicas nucleares e isotópicas para la investigación de la contaminación marina. Crónicas, Boletín del OIE 2: 2-7.

McIntosh D, Fitzsimmons K. 2003. Characterization of effluent from an inland, low salinity shrimp farm: What contribution 
could this water make if used for irrigation. Aquacult. Eng. 27: $147-156$.

Mearns AJ. 1981. Effects of municipal discharges on open coastal ecosystems. Elsevier Oceanogr. Ser. 27: 25-66.

Miranda-Baeza A, Voltolina D, Brambila-Gámez MA, FríasEspiricueta M, Simental J. 2007. Effluent characteristics and nutrient loading of a semi-intensive shrimp farm in NW Mexico. Vie Milieu 57: 21-27.

Molnar N, Marchand C, Deborde J, Patrona LD, Meziane T. 2014. Seasonal pattern of the biogeochemical properties of mangrove sediments receiving shrimp farm effluents (New Caledonia). J. Aquacult. Res. Develop. 5: 262.

Montaño-Ley Y, Páez-Osuna F. 2014. Assessment of the tidal currents and pollutants dynamics associated with shrimp aquaculture effluents in SAMARE coastal lagoon (NW Mexico). Aquacult. Res. 45: 1269-1282.

Montijo-Angulo JA. 2011. Caracterización de la calidad de agua en dos ambientes costeros con potencial acuícola en el estado de Sonora. MSc thesis, Instituto Tecnológico de Guaymas, Sonora, Mexico, $56 \mathrm{pp}$.

Nixon SW. 1995. Coastal marine eutrophication: A definition, social causes, and future concerns. Ophelia 41: 199-219.

Nóbrega GN, Otero XL, Macías F, Ferreira TO. 2014. Phosphorus geochemistry in a Brazilian semiarid mangrove soil affected by shrimp farm effluents. Environ. Monitor. Assess. 186: 5749-5762.

Noriega C, Araujo M. 2009. Nitrogen and phosphorus loading in coastal watersheds in northeastern Brazil. J Coast. Res. Spec. Iss. 56: 871-875.

Osuna-Ramírez R. 2010. Condición ambiental de un ecosistema costero receptor de aguas residuales de la producción de harina de pescado en Guaymas, Sonora, México. MSc thesis, Instituto Tecnológico de Guaymas, Guaymas, Sonora, 54 pp.

Parsons TR, Maita Y. Lalli CM. 1984. A Manual of Chemical and Biological Methods for Seawater Analysis. Pergamon Press, New York, 173 pp.

Páez-Osuna F. 2001. Flujos y balances de masas de nutrientes en estanques camaronícolas. In: Páez-Osuna $F$ (ed.), Camaronicultura y Medio Ambiente. Instituto de Ciencias del Mar y Limnología, Universidad Nacional Autónoma de México, pp. 176-192.

Páez-Osuna F, Gracia-Gasca A, Flores-Verdugo F, Lyle-Fritch ML, Alonso-Rodríguez R, Roque A, Ruiz-Fernández AC. 2003. Shrimp aquaculture development and the environment in the Gulf of California ecoregion. Mar. Pollut. Bull. 46: 806-815.

Penna N, Capellacci S, Ricci F. 2004. The influence of the Po River discharge on phytoplankton bloom dynamics along the coastline of Pesaro (Italy) in the Adriatic Sea. Mar. Pollut. Bull. 48: 321-326.

Pettine M, Casentini B, Fazi S, Giovanardi F, Pagnotta R. 2007. A revisitation of TRIX for trophic status assessment in the light of the European Water Framework Directive: Application to Italian coastal waters. Mar. Pollut. Bull. 54: 1413-1426.

Pinckney JL, Paerl HW, Tester P, Richardson TL. 2001. The role of nutrient loading and eutrophication in estuarine ecology. Environ. Health Perspect. 109: 699-706.
Primavera JH. 2006. Overcoming the impacts of aquaculture on the coastal zone. Ocean Coast. Manag. 49: 531-545.

Reynaga-Franco F. 2009. Análisis comparativo de parámetros del agua y estado trófico de tres lagunas costeras del estado de Sonora, México. Instituto Tecnológico del Valle del Yaqui, Bacum, Sonora, 46 pp.

Rosales-Flores K. 2012. Efecto de un cultivo de camarón (Litopenaeus vannamei) en jaulas sumergibles sobre la calidad del agua y sedimento en la Bahía de San Francisco, Guaymas, Sonora, México. BSc thesis, Instituto Tecnológico de Bahía de Banderas, Nayarit, México, 76 pp.

Rosenberg R. 1985. Eutrophication: the future marine coastal nuisance? Mar. Pollut. Bull. 16: 227-231.

Salas F, Texeira H, Marcos C, Marques JC, Pérez-Ruzafa A. 2008. Applicability of the trophic index TRIX in two transitional ecosystems: the Mar Menor lagoon (Spain) and the Mondego estuary (Portugal). ICES J. Mar. Sci. 65: 1442-1448.

Sánchez E, Colmenarejo MF, Vicente J, Rubio A, García MG, Travieso L, Borja R. 2007. Use of the water quality index and dissolved oxygen deficit as simple indicators of watersheds pollution. Ecol. Indicat. 7: 315-328.

Santamaría-del-Angel E, Álvarez-Borrego S, Müller-Karger FE. 1994. Gulf of California biogeographic regions based on coastal zone color scanner imagery. J. Geophys. Res. (Oceans) 99: 7411-7421.

Sarà G. 2007. A meta-analysis on the ecological effects of aquaculture on the water column: dissolved nutrients. Mar. Environ. Res. 63: 390-408.

Strickland JDH, Parsons TR. 1972. A Practical Handbook of Seawater Analysis. Fish. Res. Board Canada 167: 310 pp.

Suárez-Abelenda M, Ferreira TO, Camps-Arbestain M, RiveraMonroy VH, Macías F, Nuto Nóbrega G, Otero XL. 2014. The effect of nutrient-rich effluents from shrimp farming on mangrove soil carbon storage and geochemistry under semi-arid climate conditions in northern Brazil. Geoderma 213: 551-559.

Symonds AM. 2011. A comparison between far field and near field dispersion modeling on fish farm particulate wastes. Aquacult. Res. 42: 73-85.

Thuyet DB, Luong-Van J, Austin CM. 2012. Impact of shrimp farm effluent on water quality in coastal areas of the world heritagelisted Ha Long Bay. Am. J. Environ. Sci. 8: 104-116.

Troot LA, Alongi DM. 2000. The impact of shrimp pond effluent on water quality and phytoplankton biomass in a tropical mangrove estuary. Mar. Pollut. Bull. 40: 947-951.

Vollenweider RA, Giovanardi F, Montanari G, Rinaldi A. 1998. Characterization of the trophic conditions of marine coastal waters with special reference to the NW Adriatic Sea: Proposal for a trophic scale, turbidity and generalized water quality index. Environmetrics 9: 329-357.

Wu RSS, Lam KS. 1994. Impact of marine fish farming on water quality and bottom sediment: A case study in the sub-tropical environment. Mar. Environ. Res, 38: 115-145.

Wulff F, Rahm L, Hallin AK, Sandberg J. 2001. A nutrient budget model of the Baltic Sea. In: Wulff F, Rahm L, Larsson P (eds.), A Systems Analysis of the Baltic Sea, Ecological Studies 148, Springer-Verlag, Berlin, pp. 353-372.

Received March 2014, accepted November 2014 